\title{
Estruturas atectônicas da Bacia do Paraná em Campinas (SP): deformação sin-sedimentar no Subgrupo Itararé
}

\author{
Celso Dal Ré Carneiro \\ Departamento de Geociências Aplicadas ao Ensino \\ Instituto de Geociências - Unicamp \\ cedrec@ige.unicamp.br \\ Felipe Garcia Domingues da Costa \\ Graduando em Geologia \\ Instituto de Geociências - Unicamp \\ felipe.domingues@ige.unicamp.br
}

* Este documento deve ser referido como segue:

Carneiro C.D.R., Costa F.G.D.da. 2006. Estruturas atectônicas da Bacia do Paraná em Campinas (SP): deformação sin-sedimentar no Subgrupo Itararé. Terræ Didatica, 2(1):34-53. <http:// www.ige.unicamp.br/ terraedidatica/>
RESUMO

Entre 2000-2001, obras na Rodovia D. Pedro I expuseram dobras atectônicas no Subgrupo Itararé, Bacia do Paraná, no trevo da estrada que une Campinas a Moji-Mirim e Moji-Guaçu. Ocorrem dobras convolutas decimétricas, fechadas a isoclinais, controladas por siltitos laminados. As obras também expuseram, $e$ depois destruíram, ondulaçôes com comprimento de onda da ordem de $20 \mathrm{~m}$. Sintetizamse critérios distintivos desse tipo de estrutura e descrevem-se feições similares, entre SP e SC. A origem das deformações pode ser associada diretamente à ação do gelo ou ao deslizamento subaqüoso de camadas inconsolidadas. As ocorrências de Campinas parecem resultar de ambos os processos. Localmente, camadas não-confinadas em ambiente subaqüoso sofreram deformações penecontemporâneas à sedimentação, ao passo que as ondulações mais amplas e abertas devem-se à ação direta do gelo.

PALAVRAS-CHAVE Estruturas atectônicas, deformação penecontemporânea, dobras convolutas, Subgrupo Itararé, Bacia do Paraná

ABSTRACT Between 2000-2001, new outcrops of convolute folds have been discovered at the Highway D. Pedro I, in the interconnection with the Campinas to Moji-Mirim and Moji-Guaçu Highway. The features are typical atectonic folds. A level of weathered laminated siltites exhibits tight to isoclinal folds in rocks of the Itararé Subgroup (Tubarão Group). Open folds in sandstones and siltites have also been displayed, but soon later they were destroyed. This paper sinthezises distinctive criteria for atectonic structures and describes similar features elsewhere. Two main alternatives for the origin of the deformations are considered: direct action of ice movements or gravitational dislocations of unconfined inconsolidated layers. Data integration indicates that the two types of occurrences at Campinas result of both processes, but the later mechanism explains better the described convolute folds.

KEYWORDS Non-tectonic structures, penecontemporaneous deformation, convolute folds, Itararé Subgroup, Paraná Basin 


\section{Introdução}

Obras de modernização da SP-65, Rodovia D. Pedro I, no trecho em que esta estrada estadual contorna a cidade de Campinas, no Estado de São Paulo, expuseram, entre 2000-2001, rochas sedimentares dobradas pertencentes ao Subgrupo Itararé (Grupo Tubarão), da borda da Bacia Sedimentar do Paraná. As estruturas variam desde ondulações abertas até dobras bastante contorcidas. Caracterizadas como típicas estruturas atectônicas, apresentam-se bem expostas no trevo da SP-340, Rod. Gov. Dr. Adhemar P. de Barros, que une Campinas às cidades de Moji-Mirim e Moji-Guaçu. Em parte, as exposições foram destruídas durante as obras de modificação do trevo, mas outras ainda são visíveis (Fig. 1).

As camadas dobradas da Figura 1, com espessuras centimétricas a decimétricas, fazem parte de uma sucessão, na qual estas se intercalam com camadas indeformadas. Carneiro e Costa (2006) admitem duas hipóteses para a sua origem: deformações causadas por movimentação dos gelos e deslizamento subaqüoso; assinalam que ambas se aplicam a dados recolhidos no local aqui descrito, mas em dois pontos distintos. Para estudar em campo exposições de estruturas similares na borda da Bacia do Paraná entre SP e SC, diversos afloramentos foram visitados (Costa e Carneiro 2006), para comparação com as feições típicas identificadas em Campinas.

As observações contidas em Carneiro e Costa (2006) precedem a revegetação artificial que hoje dificulta a observação, pois datam da época da abertura dos cortes. Os dados disponíveis referem-se a uma parte das ocorrências, porque outras feições notáveis foram expostas e em seguida destruídas pelas obras de duplicação da Rod. D. Pedro I. Durante as obras no trevo de Moji-Mirim / MojiGuaçu, um dos autores (CDRC) visitou os cortes em vários momentos; foram observados anticlinais e sinclinais abertos de comprimentos de onda métricos, arqueamentos suaves e interdigitações entre camadas de arenitos, siltitos e argilitos. À margem da antiga pista simples da rodovia havia exposições de diamictitos que foram eliminadas. O nível de camadas dobradas centimétricas, intercaladas em camadas indeformadas, do Subgrupo Itararé (Grupo Tubarão) ficou preservado em pequena elevação de formato aproximadamente triangular, entre as alças de acesso da Rod. D. Pedro I (SP-65,

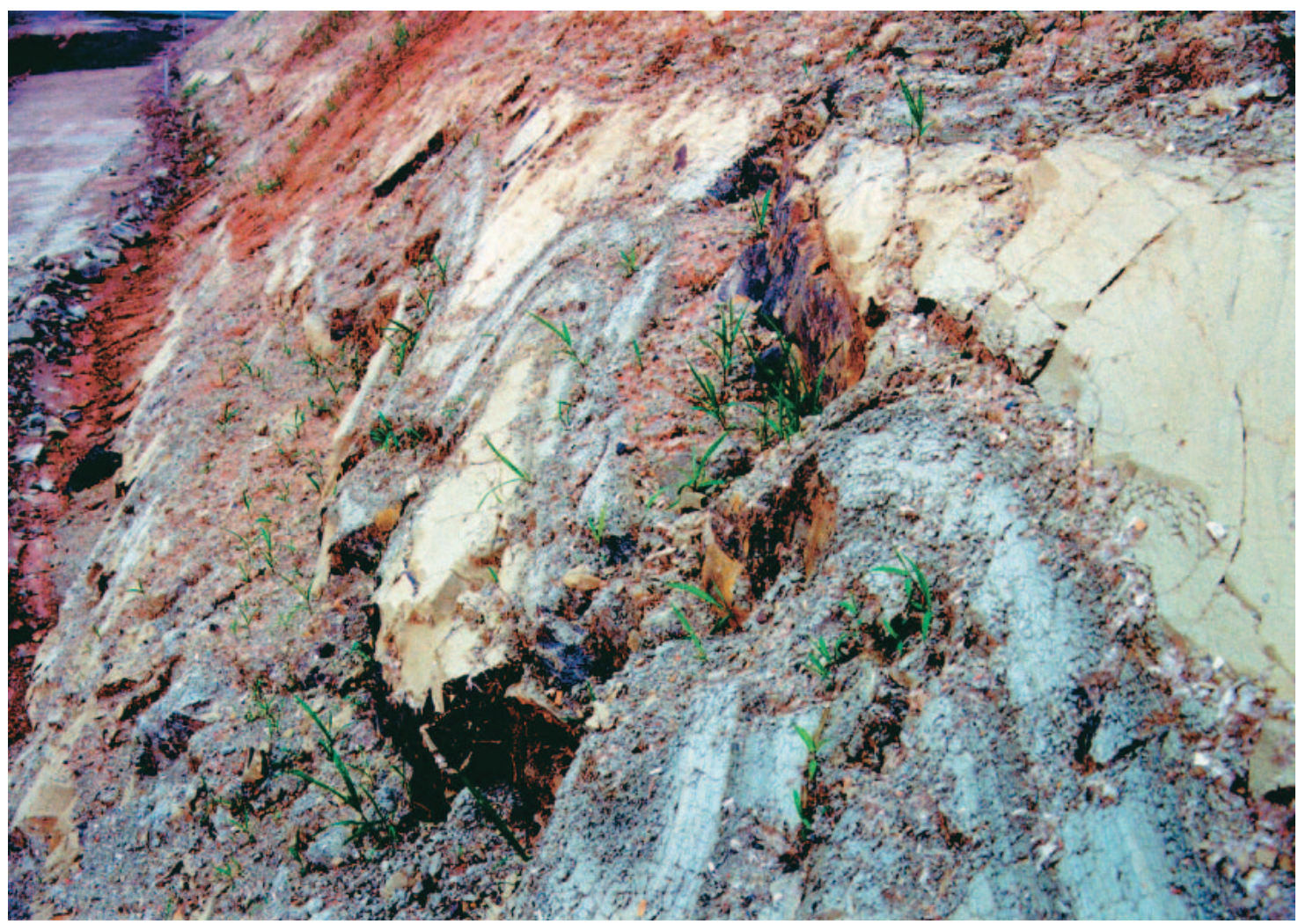

Figura 1 - Sucessão de estruturas dobradas no trevo da Rodovia Dom Pedro I 


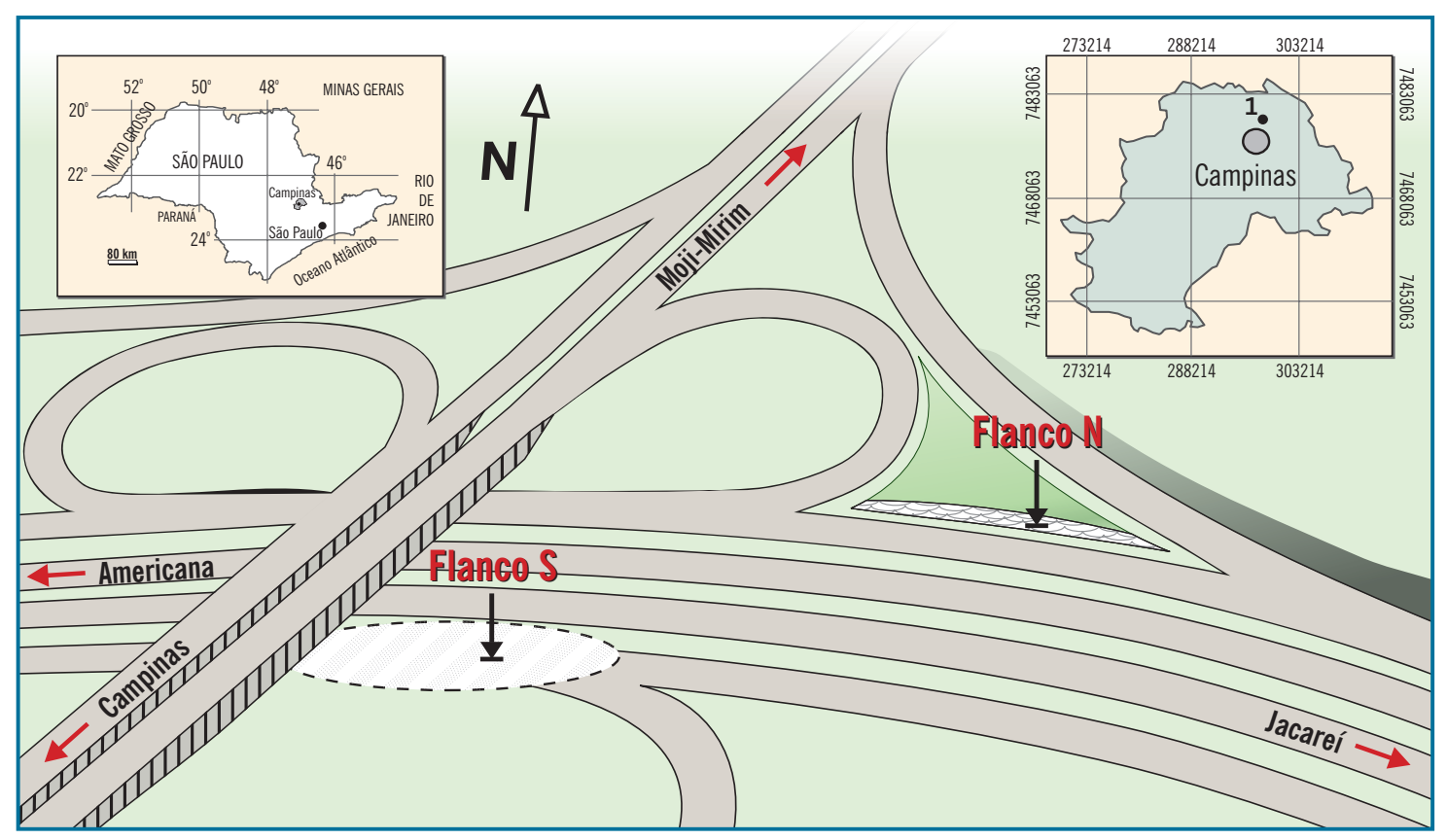

Figura 2 - Localização do afloramento descrito de estruturas atectônicas, flancos norte (N) e sul (S) dos cortes de estrada em Campinas, Estado de São Paulo. Imagem local obtida por meio do programa Goog/e Earth

pista Jacareí-Campinas), para a Rod. SP-340 (pista Campinas-Moji-Mirim) (Fig. 2).

A presente nota visa a descrever e caracterizar estruturas atectônicas do tipo dobras convolutas e outras, tendo como referência as feições presentes no trevo da Rod. D. Pedro I em Campinas. Um banco de dados construído a partir de levantamento bibliográfico possibilitou a visita e posterior descrição de algumas feições similares, encontradas em outros locais da bacia. A partir da apreciação desse conjunto de informações, pretende-se contribuir para o entendimento da origem das estruturas atectônicas do Subgrupo Itararé. A nota destina-se ainda a sintetizar conceitos sobre tal categoria de estruturas, além de apresentar e discutir resultados de análise estrutural em campo.

\section{Estruturas atectônicas: conceitos básicos}

Estruturas atectônicas são arranjos que se desenvolvem nas rochas, especialmente as sedimentares, devido a movimentos causados fundamentalmente pela ação da força da gravidade sobre massas rochosas destituídas de suporte ou apoio; sua ocorrência é localizada, sendo restritas as condições de identificação e observação; normalmente essas feições ocorrem em áreas pequenas. Afetam, principalmente, sedimentos na superfície do terreno ou em níveis próximos a ela, e manifestam-se, em geral, por meio de dobras e pequenas falhas, ditas atectônicas. A origem dessas estruturas independe de deformações dos níveis profundos da crosta; portanto, não requer propagação de forças internas através do substrato rochoso no qual se apóiam. A designação decorre do fato de serem formadas sem participação de esforços de origem tectônica ou relacionados a diastrofismo (Loczy e Ladeira 1976).

Estruturas atectônicas formam-se durante a própria deposição de sedimentos, antes de serem cobertos por camadas mais jovens, ou ainda, desenvolvem-se nos sedimentos após sua formação, mas sem intervenção de tectonismo. Podem resultar, assim, de processos superficiais comumente relacionados a fenômenos de erosão e deposição.

Compactação e diagênese dos sedimentos por gravidade e compactação diferencial são algumas das formas pelas quais as diferentes estruturas de rochas podem ser formadas. Estruturas atectônicas dobradas podem se formar por compactação diferencial ou deslizamentos subaqüosos. A densidade dos sedimentos é determinada não apenas pela composição das partículas sólidas, mas também pelo seu conteúdo em água e gases (derivados da decomposição de matéria orgânica, Hobbs et al. 1976). Quando a compactação por gravidade atua sobre sedimentos homogêneos de considerável extensão lateral, depositados sobre uma superfície plana e quase horizontal, podem ser notados efeitos como 
redução em espessura e porosidade e aumento da densidade dos materiais. O comportamento geral das camadas não mudará, não se formando uma estrutura nova. Entretanto, se os sedimentos se acumularem em uma superfície que apresente alguma inclinação, ou até mesmo um relevo acentuado, ou se houver mudança lateral no caráter dos sedimentos, além de uma superfície de deposição irregular e de material menos poroso, poderá ocorrer compactação diferencial, originando estruturas atectônicas como dobras (Loczy e Ladeira 1976).

Dobras convolutas são aquelas cuja superfície axial não é planar (Twiss e Moores 1992). Também denominadas laminações convolutas, são comuns em ritmitos formados por intercalações argilosas e siltosas (Hobbs et al. 1976, p. 156-157). Embora dobras de origem tectônica também possam exibir superfície axial não-planar, é comum que a origem de muitas dobras convolutas seja independente de esforços tectônicos; o movimento de correntes sobre sedimentos depositados em superfícies suavemente inclinadas pode produzir uma sucessão de pequenas ondulações ou micro-dobras mais ou menos irregulares entre dois níveis mais plásticos da seqüência. A origem destas diferencia-se das dobras de escorregamento ("slump-folds") pois as microdobras da laminação convoluta acham-se compreeendidas entre camadas paralelas entre si (Popp 1987) (ver Tab. 1).

Deslizamentos subaqüosos também podem formar estruturas. Sedimentos depositados em uma superfície de inclinação maior que seu ângulo de repouso tendem, nesta posição instável, a deslizar sobre a superfície. A deformação associada a falhas complexas dos planos de acamamento, provocadas por deslizamentos, denomina-se slip bedding (literalmente: deslizamento de camadas).

Hobbs et al. (1976, p. 157-159) enumeram uma série de critérios para distingüir as laminações convolutas de outras estruturas de origem tectônica (Tab. 1). Esses autores ponderam, contudo, que a separação dos dois grupos possa ser artificial, já que é razoável assumir que dobras possam se formar em rochas representativas "de todos os estágios de

Tabela 1 - Critérios conclusivos, indicativos, ou pouco conclusivos, para distinção entre laminações convolutas e estruturas de origem tectônica (Hobbs et al. 1976, p. 157-159)

\begin{tabular}{|c|c|c|c|}
\hline $\mathbb{N}^{0}$ & Gritério & Origem Atectônica & Origem Tectônica \\
\hline 1 & $\begin{array}{l}\text { Existência, no material deformado, de tocas e cavidades indeformadas, } \\
\text { abertas por animais em sedimento inconsolidado }\end{array}$ & Conclusivo & - \\
\hline 2 & $\begin{array}{l}\text { Existência de flexão, ao redor das zonas de charneira, de foliações } \\
\text { metamórficas, cristais metamórficos ou grãos minerais }\end{array}$ & - & Conclusivo \\
\hline 3 & $\begin{array}{l}\text { Presença de fósseis deformados. Fósseis podem se deformar após o } \\
\text { dobramento, mas se houver relações sistemáticas entre eles e } \\
\text { as dobras, é um bom critério }\end{array}$ & - & Conclusivo \\
\hline 4 & Presença de estruturas normais e reversas em pequenas distâncias & Indicativo & Indicativo \\
\hline 5 & $\begin{array}{l}\text { Camadas dobradas truncadas por camada indeformada sobrejacente, } \\
\text { atribuída à erosão do sedimento deformado, antes da nova deposição }\end{array}$ & Indicativo & $\begin{array}{l}\text { Raramente } \\
\text { indicativo }\end{array}$ \\
\hline 6 & $\begin{array}{l}\text { Aspecto e orientação não relacionados com outras estruturas } \\
\text { de origem tectônica da área }\end{array}$ & Difícil aplicação & Difícil aplicação \\
\hline 7 & Ausência de juntas que possam ser relacionadas com as dobras & Indicativo & - \\
\hline 8 & Ausência de veios que possam ser relacionados com as dobras & $\begin{array}{l}\text { Raramente } \\
\text { conclusivo }\end{array}$ & - \\
\hline 9 & $\begin{array}{l}\text { Presença de foliação plano-axial (raramente podem ser encontradas } \\
\text { foliações plano-axiais em dobras penecontemporâneas) }\end{array}$ & Indicativo & Indicativo \\
\hline 10 & Dobras confinadas a uma camada ou a um grupo de camadas adjacentes & Indicativo & Indicativo \\
\hline 11 & Dobras caóticas & $\begin{array}{l}\text { Indicativo de } \\
\text { sedimento } \\
\text { não- consolidado }\end{array}$ & Indicativo \\
\hline
\end{tabular}


litificação". Assinala-se que os critérios devem ser utilizados de modo combinado. Isoladamente, poucos deles são conclusivos. Neste trabalho, alguns exemplos são detalhadamente apresentados e analisados, a partir de afloramentos identificados na região de Campinas (SP). A Figura 3 ilustra estruturas do flanco $\mathrm{S}$ (Fig. 2).

\section{Materiais e métodos}

Um levantamento bibliográfico inicial buscou localizar descrições de feições similares que possibilitassem interpretar os processos formadores das estruturas atectônicas estudadas. Os dados de feições associadas ao terceiro episódio de ingressões marinhas na Bacia do Paraná (Almeida e Carneiro 2004) foram organizados em banco de dados, tendo sido estabelecidas divisões hierárquicas segundo o tema do artigo e sua relação com o enfoque do presente trabalho.

\section{Banco de dados sobre estruturas atectônicas da Bacia do Paraná}

Com a finalidade de identificar na bibliografia estudos detalhados sobre estruturas da borda da Bacia Sedimentar do Paraná, realizou-se varredura de trabalhos publicados em periódicos brasileiros: no total, mais de 900 publicações foram analisadas. Dentre 1.297 volumes de periódicos, encontrouse número razoável de trabalhos sobre "estruturas atectônicas da Bacia do Paraná”. A seleção dos trabalhos que possuíam conteúdo relevante sobre estruturas atectônicas possibilitou construir uma classificação com seis níveis de interesse conforme o conteúdo, resumidos na Tabela 2.

Tabela 2 - Classificação hierárquica da bibliografia recuperada de estruturas atectônicas

\begin{tabular}{|c|c|}
\hline Nível & Trabaliho contém \\
\hline A & $\begin{array}{l}\text { Referências a Estruturas Atectônicas (fotos } \\
\text { e descrições) no Subgrupo Itararé }\end{array}$ \\
\hline$B$ & $\begin{array}{l}\text { Referências a Estruturas Atectônicas (fotos } \\
\text { e descrições) na Bacia do Paraná }\end{array}$ \\
\hline C & Alguma referência a Estruturas Atectônicas \\
\hline D & Relacionamento com o Subgrupo Itararé \\
\hline E & Relacionamento com a Bacia do Paraná \\
\hline $\mathrm{F}$ & Alguma referência à Bacia do Paraná \\
\hline
\end{tabular}

As referências bibliográficas foram dispostas em planilha contendo dados úteis para facilitar sua recuperação. O Banco de Dados reúne 121 artigos relevantes para o tema da pesquisa classificados segundo o conteúdo e importância; esses dados orientaram a seleção de pontos para visitas de campo.

\section{Descrições de Campo}

A viagem abrangeu localidades dos Estados de São Paulo, Paraná e Santa Catarina, na borda oriental da Bacia Sedimentar do Paraná. Dentre os pontos previamente catalogados no levantamento de artigos, alguns puderam ser localizados com mais precisão, graças ao apoio de profissionais a quem os Autores manifestam sua gratidão, no item Agradecimentos. Além desses, outros locais foram também incluídos nas visitas.

Realizou-se descrição pormenorizada das dobras do corte da Rod. D. Pedro I, tendo sido confeccionados diagramas estruturais e efetuada classificação segundo o método das isógonas de mergulho (Ramsay 1967, 1987), técnica de uso corrente em Geologia Estrutural. Utilizando softwares adequados, as fotografias obtidas do afloramento estudado foram digitalizadas por meio de scanner e sofreram ajustes e correções; posteriormente, as estruturas foram desenhadas de forma detalhada.

\section{Estudos anteriores}

A vasta bibliografia sobre evolução e caracterização da Bacia do Paraná inclui estudos que fazem referência específica a estruturas atectônicas no pacote permo-carbonífero. São bem menos numerosas as referências a estruturas penecontemporâneas, como deslizamento subaqüoso, laminação convoluta e deformação por carga; diversos artigos indicam precisamente a localização de pontos representativos.

A origem glacial das camadas Itararé foi proposta por Derby (1878 apud Gama Jr. et al. 1992a); Pacheco utilizara a designação "Glacial” (1927 apud Mezzalira et al. 1981) para rochas permo-carboníferas, reunidas por Washburne (1930) como Série Itararé. Mapeamentos e descrições revelam a existência de rochas pertencentes à unidade em São Paulo (Barbosa e Almeida 1949, Almeida e Barbosa 1953), Mato Grosso (Almeida 1945), além de folhelhos várvicos no sul do país (Oliveira 1929). Mendes (1962 apud Mezzalira et al. 1981) considerou a Série Itararé, juntamente com a unidade Guatá, 
subgrupos do Grupo Tubarão que identificou. Desde os primeiros estudos, feições de deformação associada ao movimento do gelo vieram sendo registradas em trabalhos que analisam a evolução e dinâmica do Subgrupo Itararé, como p.ex.

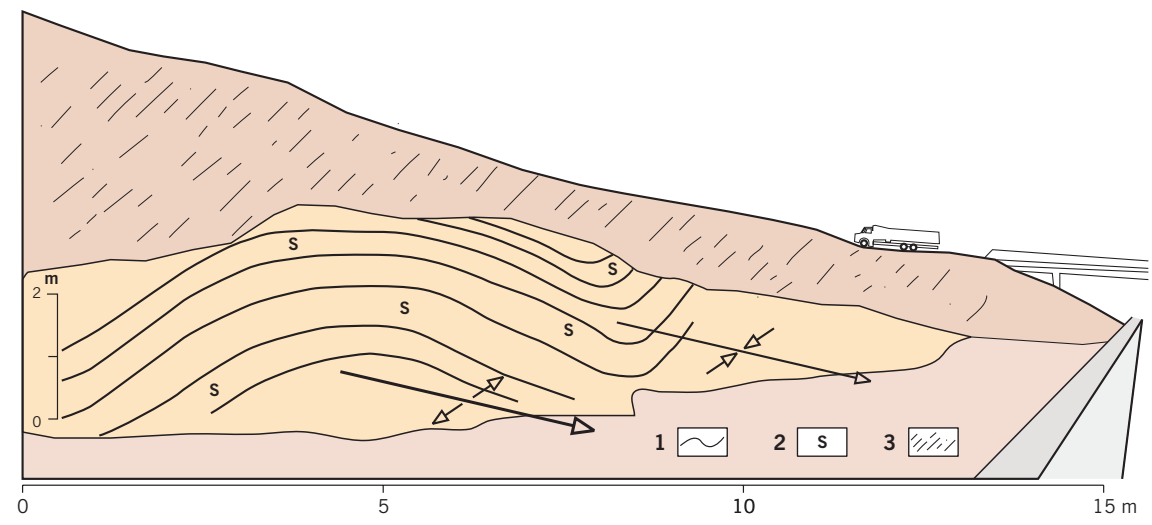

Washburne (1930), Almeida (1953), Mezzalira (1969), Rocha-Campos et al. (1969), Medeiros (1971), Fulfaro et al. (1971) e Trosdtorf et al. (2005).

Gama Jr. et al. (1992a), dentre outros, propõem hipóteses para a formação de estruturas atectônicas, apresentam descrições de estruturas relacionadas à ação do gelo e destacam a abundância das fácies de ressedimentação como componente dos ambientes peri-glaciais, onde a sedimentação é gerada por fluxos gravitacionais subaqüosos a partir de retrabalhamento de tilitos. As geleiras atuariam no suprimento de terrígenos, enquanto os verdadeiros agentes deposicionais seriam os fluxos gravitacionais.

Schneider et al. (1974) e Soares et al. (1977), dentre outros, revisam propostas de subdivisão estratigráfica do Subgrupo Itararé; Soares et al. (1977) reconhecem a dificuldade de se estabelecer limites claros entre formações pela falta de continuidade lateral dos pacotes rochosos e ausência de camadasguia, e identificam quatro associações litológicas nas quais são comuns as estruturas de laminação convoluta, camadas contorcidas e marcas de sobrecarga simétricas, em uma área geograficamente limitada. Vesely e Assine (2004) apresentam resultados de análise estratigráfica do Subgrupo Itararé na região norte do Paraná, tendo identificado cinco seqüências deposicionais, que denominaram 1, 2 , 3, 4 e 5. Dobras de escorregamento e planos de escorregamento são comuns em duas das associações litológicas descritas por Soares et al. (1977).

Baseados na análise da geometria, natureza dos depósitos associados, regime de deformação e estruturas presentes em várias exposições do Subgrupo Itararé, Vesely et al. (2005) definem quatro estilos deformacionais predominantes, dois de natureza distensiva e dois de caráter compressivo. Seriam estruturas formadas sob regimes distensivos: (a) falhas normais e basculamento de camadas; (b) superfícies de deslizamento intraestratais e dobras.

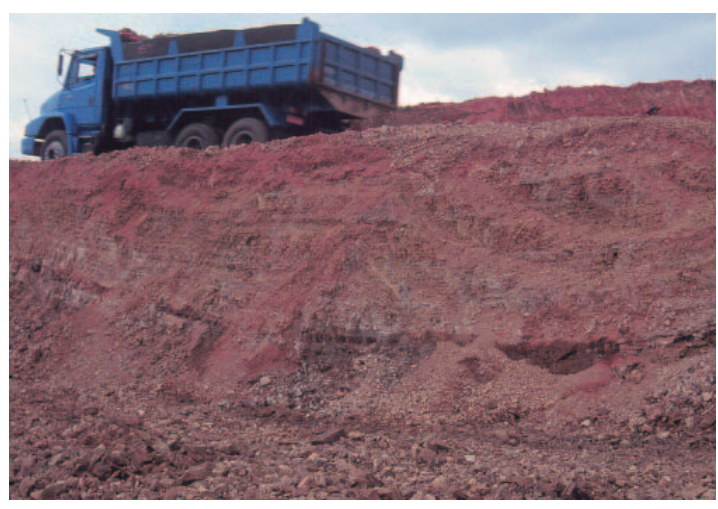

Figura 3 - Duas visões em perspectiva do afloramento, lado sul: (a) esboço geral do corte no traçado SENW, com destaque para sucessão de anticlinal e sinclinal. Símbolos: 1 - planos de estratificação dobrada, 2 - siltitos, 3 - solos; (b) aspecto do ângulo suave de abertura de sinclinal, no mesmo corte, rumo ESE, na sucessão das dobras observadas em (a)

Reconheceram, como estruturas formadas sob regimes compressivos: (c) sobrecarga, diapirismo e dobras; (d) dobras e falhas de empurrão. Assinalam que a interpretação de "uma origem gláciotectônica para as feições compressivas" fica prejudicada, nesses locais, pela inexistência de tilitos autênticos (depósitos glaciogênicos) e superfícies de abrasão glacial associadas às estruturas. Ademais, faltam exposições contínuas que, segundo esses autores, facilitariam o estabelecimento de relações espaciais entre os vários tipos.

\section{Os cortes da rodovia D. Pedro I}

No trevo de Moji Mirim, antes da duplicação da rodovia, os cortes marginais à pista CampinasJacareí da Rod. Dom Pedro I expunham três níveis irregulares de rochas relacionadas ao Subgrupo Itararé, entre os viadutos até então existentes. 
Um deles, no flanco sul da estrada, exibia diamictitos de identificação praticamente imediata; a limitada área exposta dificultava, porém, a distinção de horizontes e/ou determinação de atitudes. As obras de modernização expuseram níveis sub-horizontais de arenitos recobertos por camadas bem estratificadas de siltitos argilosos, onde foram identificadas ondulações amplas, suaves, com amplitudes da ordem de 5-10 m e comprimentos de onda que podem atingir $20 \mathrm{~m}$. Nenhuma dessas feições pode ser reconhecida hoje, porque a continuidade dos trabalhos destruiu os registros (Fig. 3).

Na margem oposta (norte) da Rod. Dom Pedro I (marco quilométrico 134,5 km), contudo, ao longo de extensão horizontal da ordem de 10 $\mathrm{m}$, um maciço rochoso aproximadamente triangular, situado entre alças de interligação rodoviária (Figs. 2, 4 e 5), exibe dobras desarmônicas em siltitos em nível estreito, espesso de no máximo 2 m. A localização em coordenadas UTM desse ponto é 291044/7472333; em coordenadas geográficas, $22^{\circ} 50^{\prime} 37,6^{\prime \prime}$ S e $47^{\circ} 02^{\prime} 10,8^{\prime \prime}$ W. A descrição que se segue das exposições em Campinas foi extraída de Carneiro e Costa (2006):
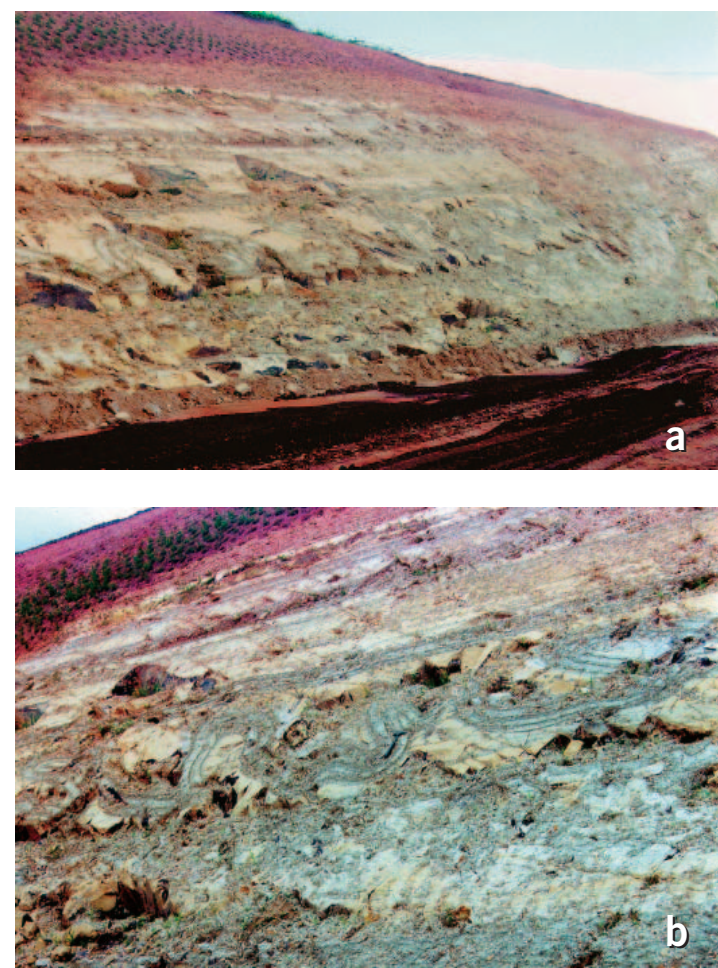

Figura 4 - Visão geral em perspectiva do afloramento: (a) visão do corte no rumo NNE, com o respectivo traçado

de contatos à direita; (b) visão do corte no rumo NNW, com destaque, à direita, para as formas sinuosas que pertencem a um horizonte muito bem definido

"No horizonte dobrado, as camadas de siltito mais espessas apresentam coloração cinza-claro, são tipicamente empastilhadas e ocasionalmente contêm seixos arredondados, de tamanho pequeno, compostos de quartzo ou quartzito. A esfericidade dos seixos é bai$x a$, sendo possivel encontrar formas facetadas em formato de 'ferro de engomar'. As camadas laminadas de siltito variam de cinza-escuro a cinza-amarelado $e$ possuem espessuras milimétricas a submilimétricas. Em alguns pontos a rocha assemelha-se a um ritmito várvico cinza-amarelo muito fino".

À altura do km 132 da Rod. Dom Pedro I, ocorrem conglomerados suportados por seixos, nos quais há muitos seixos facetados e estriados, irregulares e arrendondados, em corte defronte ao Shopping Galleria. Há pelo menos três níveis de conglomerados no corte, intercalados com siltitos argilosos e arenitos róseos. Seixos arredondados de argilitos são igualmente numerosos, muitas vezes de forma aproximadamente discóide. Desintegram-se com facilidade, ao serem pressionados nas mãos, em virtude do grau de decomposição. Revelam o predomínio, na época de deposição, de condições frias e secas, compatíveis com o ambiente periglacial (Carneiro e Costa 2006).
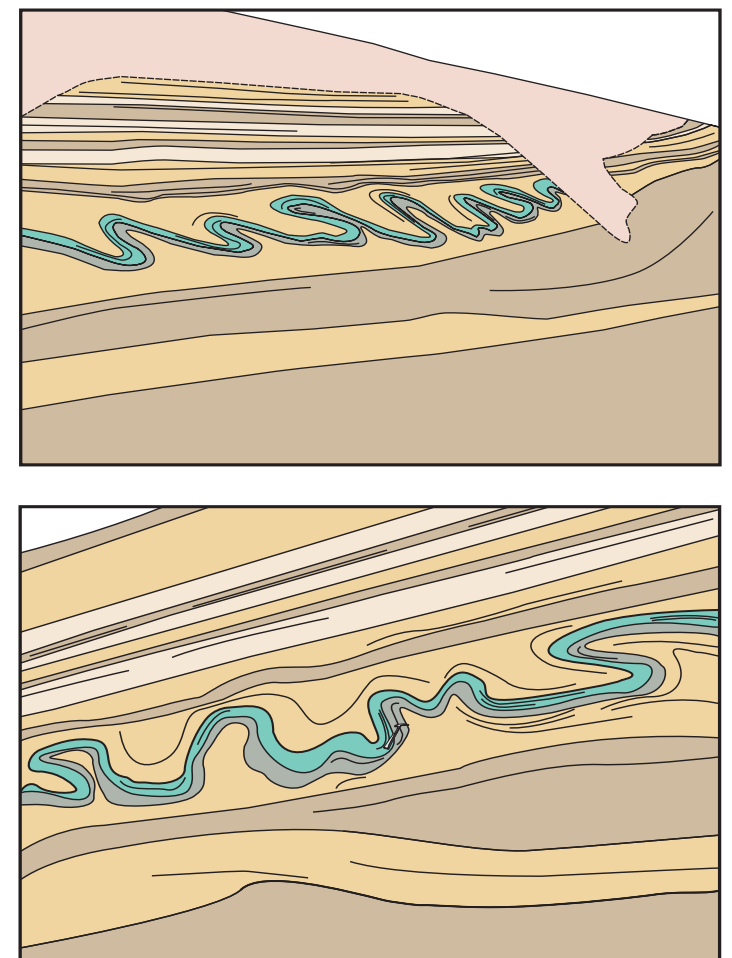


\section{Documentação fotográfica}

As figuras 4 e 5 contêm as fotografias obtidas do afloramento e correspondentes imagens editadas. Nas fotos gerais (Fig. 4) observam-se efeitos iniciais das obras de revegetação do talude, que acabaram por obliterar as estruturas, dificultando a visualização de detalhes. As linhas vermelhas, mais fortes nas imagens geradas, indicam cada camada que compõe o pacote sedimentar; linhas mais claras, alaranjadas, representam o acamamento, que coincide com a atitude da camada; as linhas verdes indicam área coberta por revegetação. Escalas foram determinadas com base no martelo geológico das fotografias, redesenhado nas imagens. Convém assinalar, obviamente, que a escala é variável, nos casos em que a "visão" proporcionada pela foto está em perspectiva.

\section{Análise estrutural}

Foram tomadas, aproximadamente, 60 medidas sistemáticas de dados de orientação, correspondentes a pequeno número de dobras (Fig. 6a). Um conjunto de dobras representado por três sinclinais e três anticlinais foi objeto de medição sistemática.
Os pólos foram plotados em rede polar, em busca da identificação de círculos máximos nos quais os pólos se encaixassem. Verifica-se que a orientação das dobras é aproximadamente coincidente. Foram igualmente plotados os pólos de eixos de dobra (Fig. 6b) como elemento geométrico importante. A análise estrutural dos dados de orientação obtidos no campo revela congruência das atitudes de eixos, que estão orientados segundo N20E, com pequenas variações de mergulho. Predominam atitudes subhorizontais (Fig. 6b).

Para estruturas de origem tectônica, o método de classificação segundo isógonas de mergulho (Ramsay 1967) divide as dobras em categorias bem definidas: 1 - isógonas convergentes, 2 - isógonas paralelas (dobras similares) e 3 - isógonas divergentes. As dobras tipo 1 são divididas em três subclasses: A: ápice espessado e flanco adelgaçado; B: espessura constante tanto no ápice como nos flancos (dobras concêntricas); C: ápice adelgaçado e flanco espessado.

Aplicando-se a técnica geométrica (Ramsay e Huber 1987) a uma imagem frontal das dobras, não se obteve um padrão uniforme de tipos. Reconheceram-se duas dobras tipo 1C, duas tipo 3, e duas
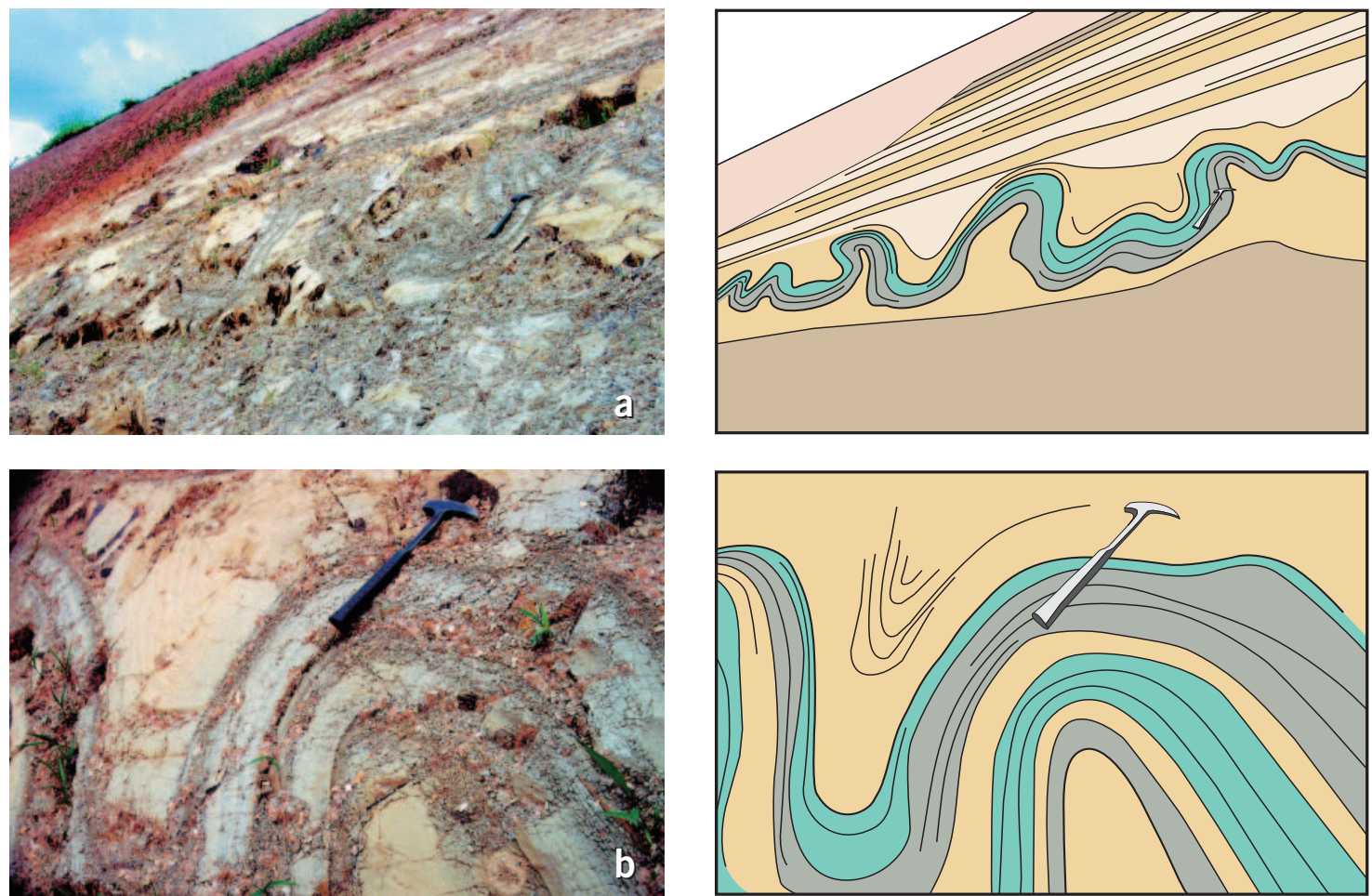

Figura 5 - Visão frontal do afloramento (a), com escala (martelo) e a representação das dobras desarmônicas à direita; visão de um sinclinal e um anticlinal isoclinais (b), com destaque, à direita, para a espessura das camadas, que se mantém quase constante, mas com leve espessamento de flancos 

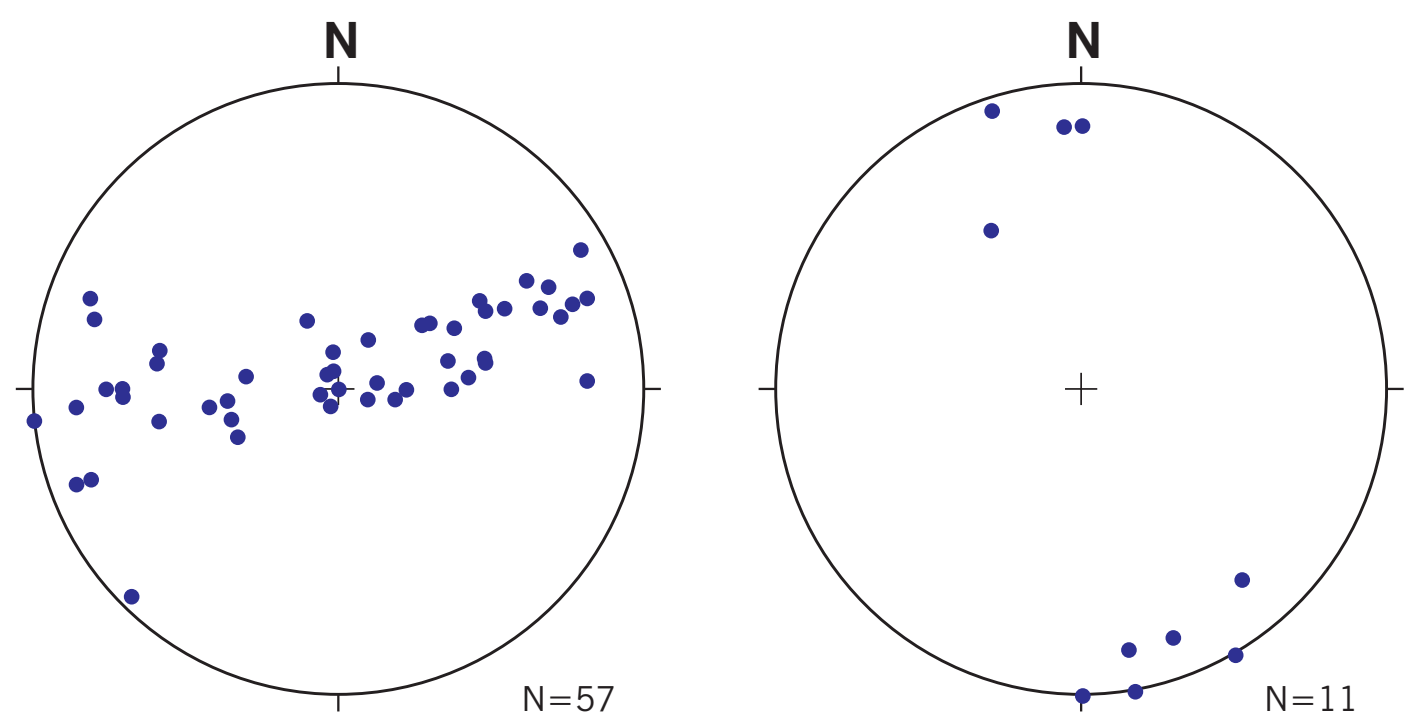

Figura 6 - Diagramas estereográficos de Schmidt-Lambert, hemisfério inferior:

(a) flancos de dobras, (b) eixos medidos de dobras

outras que apresentaram comportamento distinto entre os dois flancos. Em uma delas, os flancos foram classificados como 3 e $1 \mathrm{C}$ e, em outra, como 1A e 1B. Justifica-se tal diversidade, já que os padrões observados referem-se a estruturas atectônicas, ou seja, não representam resposta a esforços de idêntica magnitude na escala de afloramento; além disso, admitindo-se origem por deslizamento subaqüoso, a probabilidade de existir apenas dobras de um tipo seria menor do que para tipos variados, em virtude de variações da quantidade de material deslocado e sua natureza. Finalmente, o piso da superfície de deslocamento pode conter irregularidades naturais que perturbariam o sistema, redistribuindo as forças geradoras das dobras de modo caótico e não-padronizado.

\section{Estruturas atectônicas similares}

O banco de dados baseado em pesquisa bibliográfica fundamentou a seleção de pontos de visita de campo. Foram organizadas tabelas contendo dados de localização, município onde o ponto está situado, rodovia, detalhes de localização para facilitar a busca do local descrito e descrição original do afloramento. $\mathrm{O}$ trabalho mais recente que sintetiza dados de estruturas similares (Vesely et al. 2005) descreve pontos nas proximidades de Campinas (SP); Ponta Grossa e Telêmaco Borba (PR). Neste caso, a localização exata dos pontos foi obtida junto a um dos autores (MLA) sendo possível, então, completar o banco de dados e o roteiro de campo.
A Figura 7 indica a localização de estruturas atectônicas na borda oriental da Bacia do Paraná. Assim como o local descrito neste artigo, a maioria dos pontos que podem ser visitados em São Paulo pertence "ao terço inferior aflorante do Itararé" (Gama Jr. et al. 1992b). O ponto 1 localiza-se em Salto (SP), em corte da SP-308 Rodovia do Açúcar, próximo ao $\mathrm{km} \mathrm{101,} \mathrm{a} 300 \mathrm{~m}$ da ponte sobre o rio Tietê, no cruzamento com a rodovia SP-79. O afloramento exibe canal escavado em arenitos e preenchido por diamictitos de ressedimentação. Os siltitos argilosos sobrepostos aos depósitos que preencheram o canal escavado possuem geometria lenticular, exibindo sutil gradação e deformações plásticas causadas por diapirismo de lamitos (Gama Jr. et al. 1992b, p. 238).

$\mathrm{O}$ ponto 2 localiza-se em Campinas (SP), à margem da SP-348, Rod. dos Bandeirantes, km 94,5, junto ao viaduto Dunlop. O afloramento, bem exposto nos dois lados da rodovia, expõe arenitos acamadados, com feições convolutas derivadas de fluidização (Gama Jr. et al. 1992b, p. 241). As feições não correspondem, precisamente, a estruturas penecontemporâneas causadas por deformação; da mesma forma, em Itu (SP), em corte da SP-308 Rodovia do Açúcar (ponto 3), à altura do km 93,5, à direita no sentido Sorocaba-Piracicaba, afloram ritmitos gradados, nos quais o acamamento ondulado deriva da preservação, por decantação, das formas tracionais do leito arenoso. $\mathrm{Na}$ parte superior, por sobrecarga, são produzidas estruturas do tipo balls and pillows e lutocinese. 
Em Boituva (SP), junto ao km 0,5 da SP-129, Rodovia Vicente Palma, Gama Jr. et al. (1992b) descrevem afloramento portador de notáveis deformações plásticas. Uma superfície de deslizamento permitiu a movimentação e deformação de turbiditos desconfinados, mais diluídos, sobre horizontes subjacentes nos quais predominam arenitos maciços com clastos de argilitos e, subordinadamente, lamitos e/ou ritmitos intercalados. No vale do rio Sorocaba, em Cerquilho (SP), no km 98,3 da SP-127 Rodovia Cerquilho-Tatuí, há diamictitos, com baixa proporção de seixos e grânulos quartzosos e líticos. A presença de dobras e feições convolutas desenhadas pela estratificação reliquiar sugere "certo grau de organização dos diamictitos originais" (Gama Jr. et al. 1992b, p. 246). Na localidade de Eng. Maia, entre Itapeva e Itararé, Caetano-Chang et al. (1990) descrevem a existência de pavimento estriado encontrado em arenitos do próprio Subgrupo Itararé.

No km 138,3 da SP-330, Rodovia Anhangüera, entre o trevo de acesso a Artur Nogueira e Limeira, Fulfaro et al. (1971) descrevem arenito com lâminas de argila em estruturas convolutas passando para o topo a diamictitos.

As estruturas atectônicas no estado do Paraná foram localizadas com base em Canuto et al. (2001), Medeiros (1971) e Vesely et al. (2005). O trecho de estrada referido por Canuto et al. (2001) como pontos 6 e 7, situados na BR-116, estende-se ao longo de $60 \mathrm{~km}$ da rodovia, entre Quitandinha (PR) e Itaiópolis (SC); no trecho, os cortes exibem diamictitos e arenitos interestratificados e deformados e arenitos com laminação convoluta. $\mathrm{O}$ corte sob a ponte da Estrada de Ferro Rio Negro-São Francisco situa-se entre Campo do Tenente (PR) e Mafra (SC), à altura do km 105,9 da BR-116. Afloram sedimentos rítmicos; no topo do afloramento observa-se laminação ondulada assimétrica que tende a formar ondulação cuja abertura decresce para o topo e dobras convolutas (Medeiros 1971).

As estruturas atectônicas no Estado de Santa Catarina situam-se ao longo da BR-116 nas proximidades de Mafra (Medeiros 1971). Marques Filho et al. (1965) descrevem, em pormenores,

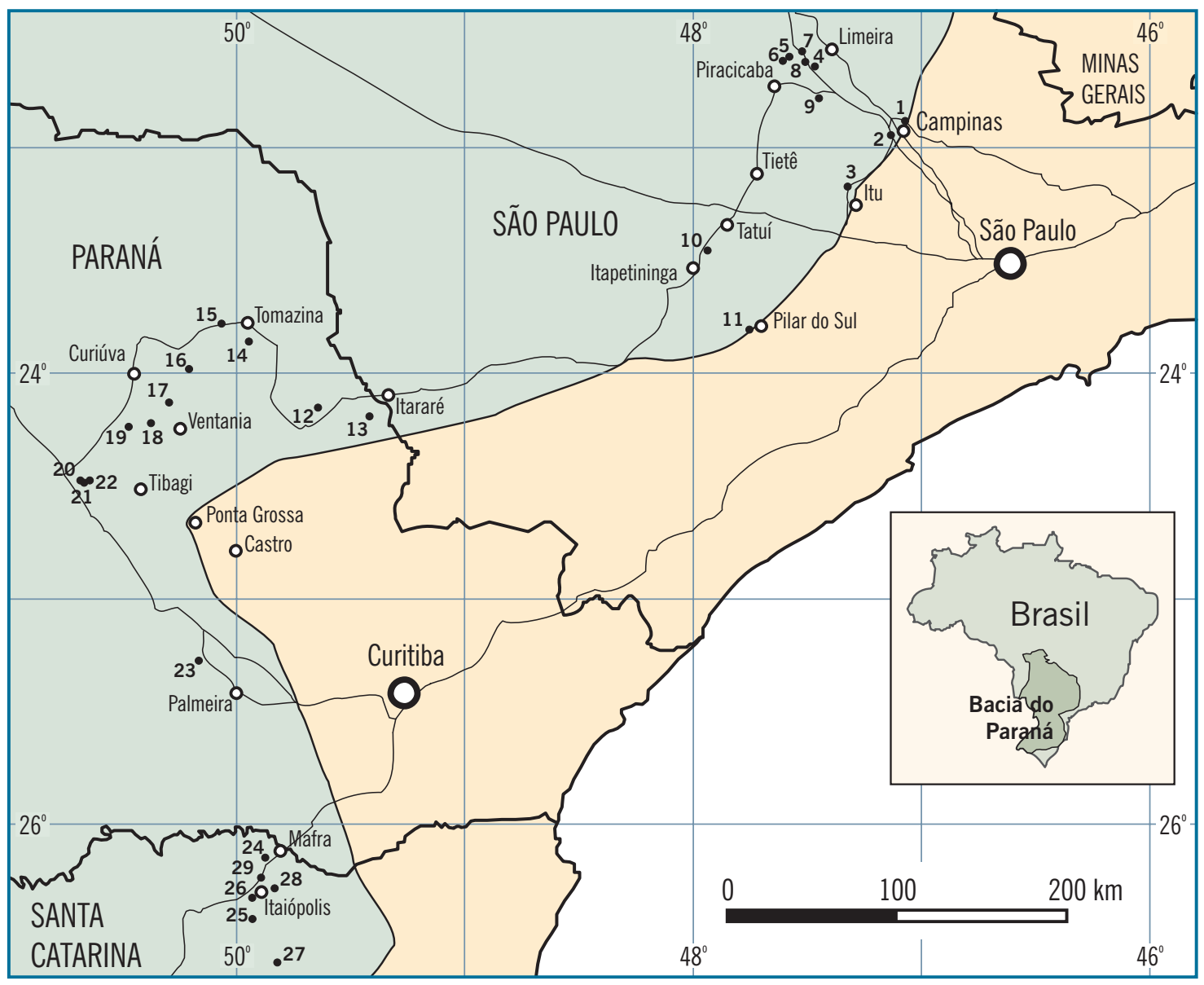

Figura 7 - Exposições selecionadas de estruturas atectônicas na borda SE da Bacia do Paraná 
Tabela 3 - Pontos visitados na Bacia do Paraná com dados de localização

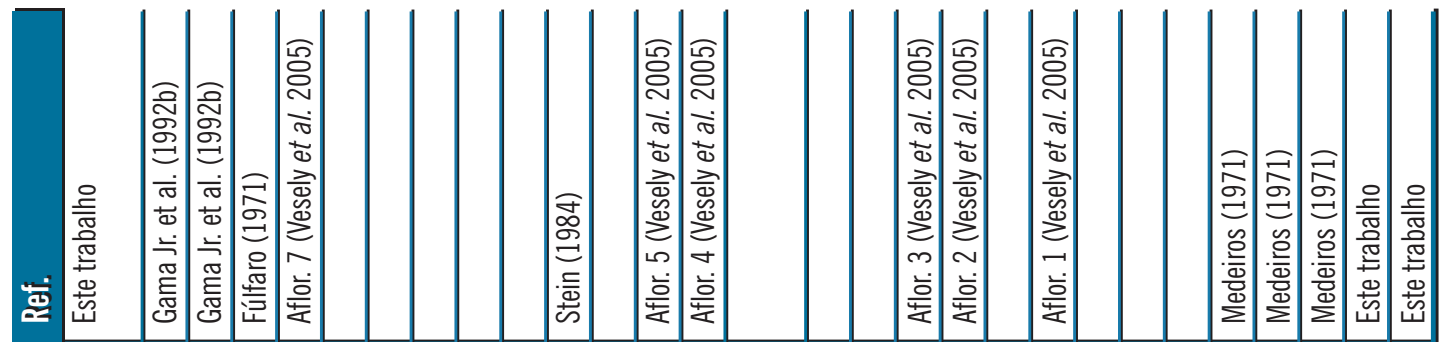

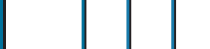

\begin{tabular}{ll|l|l|l|l|l|l|l} 
& & & & & & & &
\end{tabular}

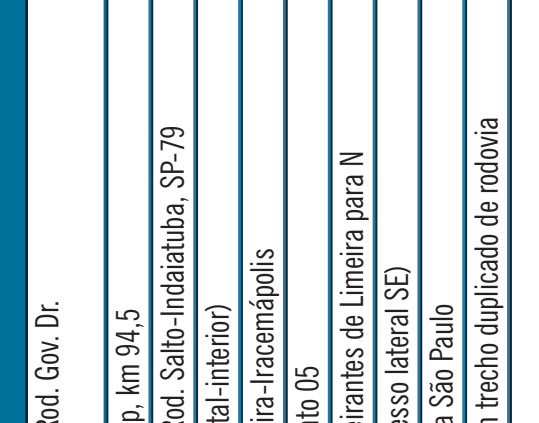

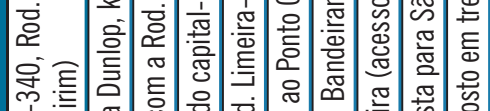

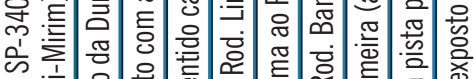

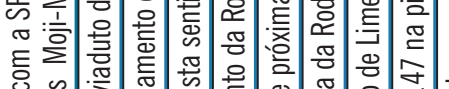
言

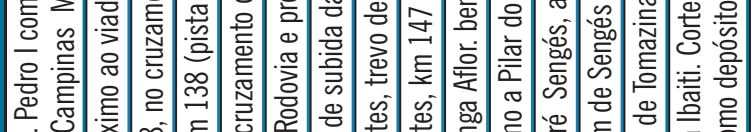

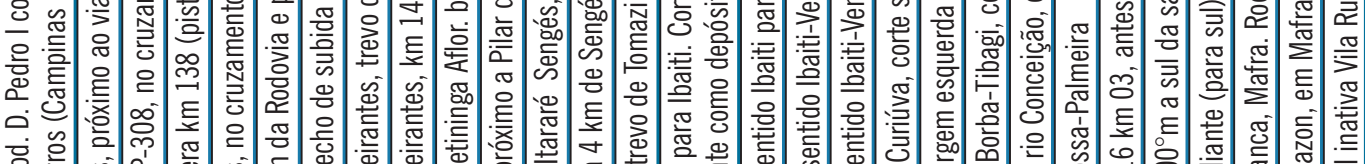

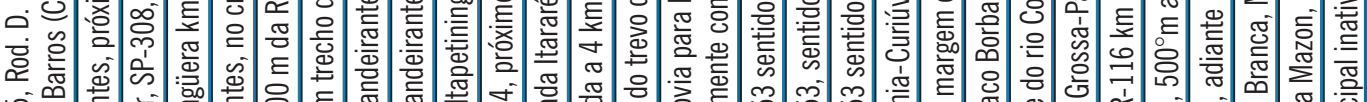

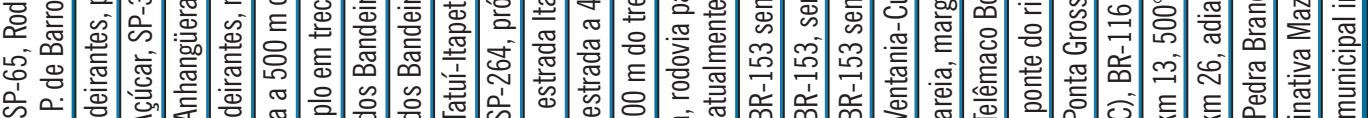

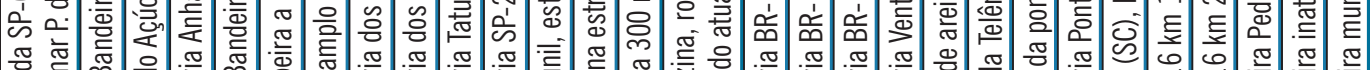

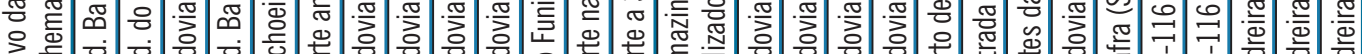

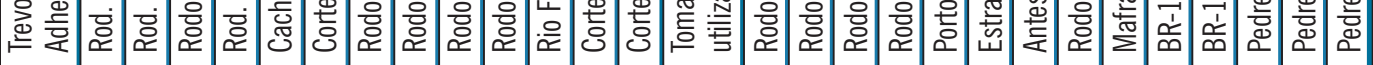

3

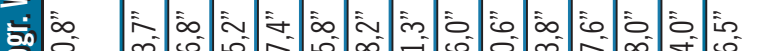

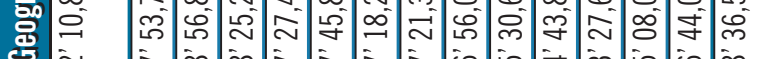

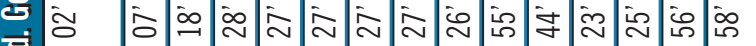

莺守

\%

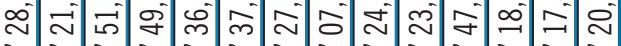

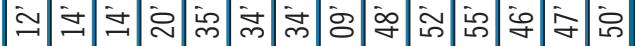

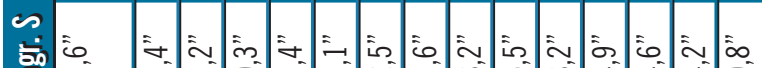

兽

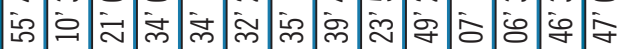

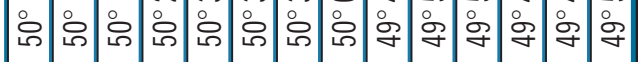

总

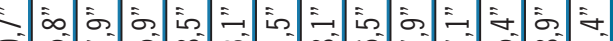

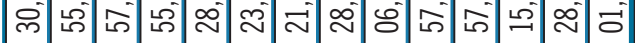

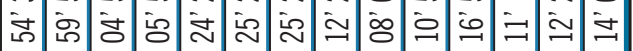

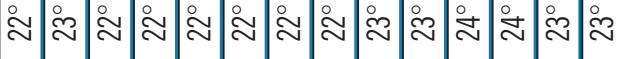

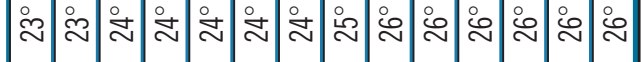

*

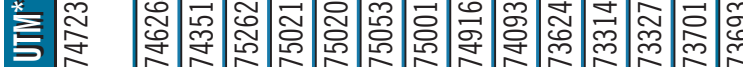

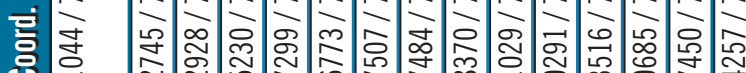

它

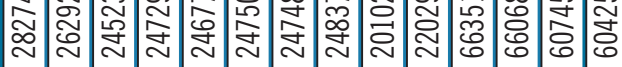

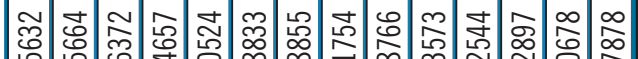

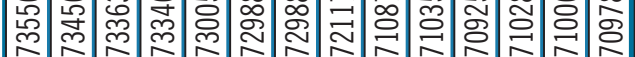

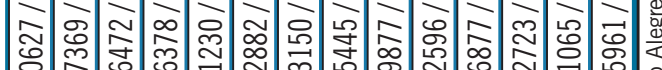

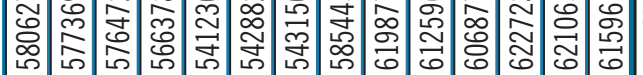


exemplos de deformações penecontemporâneas à sedimentação, todas subaqüosas, em vários locais da folha Rio Negro. Em pedreira situada à altura do km 109,1, ocorre diamictito com matriz arenosa e estrutura de escorregamento. No ponto do km 117,8, junto à saída para Canoinhas, entre Mafra e Papanduva, ocorre intercalação de arenito muito fino-siltito e argilito. No km 128,5 da BR-116, camadas centimétricas intercaladas de arenito muito fino e laminações paralelas de argilito exibem níveis com dobras convolutas que passam lateralmente a acamamento e laminação paralela. No km 130,6 da BR-116, aflora arenito muito fino, localmente fino a médio, nos quais diversas estruturas acham-se presentes, com destaque para as dobras convolutas e estruturas flaser no topo do intervalo.

\section{Feições reconhecidas entre Limeira e Salto}

No planejamento da viagem de campo, foram selecionados trabalhos que descrevem as estruturas com mais precisão. Dentre esses, alguns afloramentos antigos não foram localizados ou encontravam-se totalmente obliterados.

$\mathrm{Na}$ região aproximadamente delimitada pelas cidades paulistas de Campinas, Limeira e Pilar do Sul, há ocorrências notáveis de arenitos afetados por dobras convolutas. Na Rod. Anhangüera, km 138 (ponto 4, Tab. 3), ocorre arenito arcosiano amarelado-bege com estratificações cruzadas, em que se observa uma dobra aberta com flanco SE muito inclinado e eixo N30E horizontal. Esse ponto foi descrito por Fúlfaro (1971) como:

“(...) arenitos e diamictitos do Grupo Tubarão em contatos irregulares representando diastemas do tipo escavação e preenchimento. Os arenitos superiores apresentam grandes estratificações cruzadas ocupando uma calha cavada em arenito aparentemente maciço. Para o topo a seqüência é novamente truncada por um corpo de diamictitos seguido por argilas com vários níveis brechados. Zonas de limonitização são freqüentes no topo da seqüência.".

À margem da Rod. Limeira-Iracemápolis (ponto 6), uma cachoeira exibe níveis conglomeráticos

horizontais de cor marrom, intercalados em níveis de arenito grosso com estratificação cruzada. Os seixos angulosos são de sílex, polidos em superfície. O nível rico em seixos é posterior ao arenito com estratificação cruzada, assemelhando-se a um pavimento com cimento ferruginoso.

Os cortes amplos da Rodovia dos Bandeirantes são excelentes para observação de feições da formação Tatuí (ponto 7) e do Subgrupo Itararé, como no trevo de Limeira (ponto 8), onde ocorre arenito branco fino, com manchas amarelo-ocre, formando camadas horizontais contínuas, porém sem evidências de deformação. Na mesma rodovia, km 147 (ponto 9), há arenito muito fino branco, siltoso, laminado, com intercalações de siltito marrom avermelhado e laminações cruzadas em vários pontos. Pequenas falhas e ondulações devidas à deformação penecontemporânea distribuem-se aleatoriamente no maciço. $\mathrm{Na}$ base da seqüência há um arenito branco, homogêneo, sem laminação, mais grosso que o situado acima deste.

$\mathrm{Na}$ Rodovia Tatuí-Itapetininga, um afloramento bem exposto durante a duplicação da autoestrada, observado em dezembro de 2003, exibe dobras recumbentes isoclinais de ápices espessados, com flancos descontínuos por terem sido rompidos, conforme Figura 8. As dobras acham-se dispostas em uma sucessão de camadas subparalelas. Em outro local, correspondente ao ponto 10 (Tab. 3 ), aparecem camadas suavemente dobradas em siltitos e argilitos laminados, de cores variegadas (amarelo, vermelho, branco). 


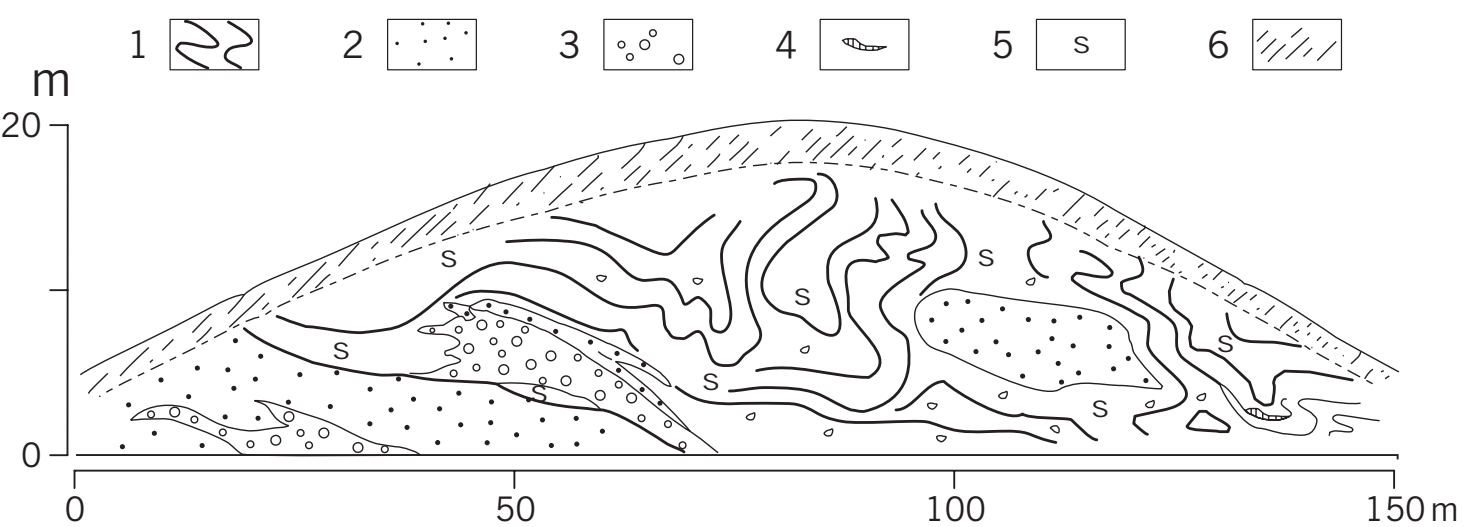

Figura 9 - Amplas dobras descritas por Stein (1984) em horizontes de siltito e arenito fino no corte da SP-264, Rod. Salto de Pirapora-São Miguel Arcanjo: 1 - Estruturas hidroplásticas; 2 - Arenito de granulação média; 3 - Conglomerado com seixos centimétricos, matriz arcosiana; 4 - Níveis lenticulares ricos em cimento carbonático; 5 - Arenito de granulação fina e siltitos com seixos pingados; 6 - Solo de alteração

Na região a norte de Pilar do Sul, em cortes da SP-264, Rod. Salto de PiraporaSão Miguel Arcanjo, Stein (1984) descreve afloramento (ponto 11) formado por camadas basais de conglomerado polimítico de matriz arenosa, em contato gradacional para arenitos imaturos, capeados por siltitos, argilitos e ritmitos. Camadas de arenitos, siltitos, conglomerado e diamictitos apresentam-se arqueadas em formas contorcidas (Fig. 9).

A norte de Porto Feliz, Washburne (1930) reconhece dobras e falhas de cavalgamento em rochas argilosas da Série Itararé (Fig. 10). O autor observa que a notável ausência de grandes depósitos de seixos, tão característicos em outras zonas continentais adiante de geleiras, pode ser explicada pela hipótese de que as massas de gelo não se achavam situadas em terra (Washburne 1930, p. 24-25), mas teriam invadido um grande lago ou lagos, possibilidade reforçada pela "abundância de argilas entre os leitos de tilito". As geleiras teriam sido suportadas "por rocha dura" na região a leste da unidade (Fig. 11). A este esboço acrescentamos um box baseado em Vesely e Assine (2004).

Almeida (1948) relata a descoberta da Rocha Moutonnée de Salto (SP), cujas estrias, implantadas na superfície de grande massa de Granito Itu, constituem prova definitiva dos movimentos de avanço e recuo que caracterizam a atividade glacial. Atualmente a área, bem como a ocorrência de varvito em Itu, constituem parques naturais de grande importância (Rocha-Campos 2002a, 2002b, Almeida e Carneiro 1995).

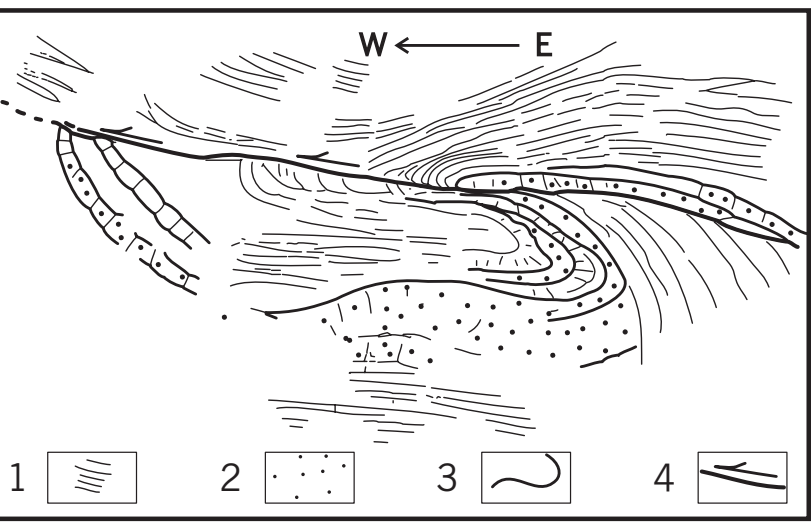

Figura 10 - Dobras e falhas de cavalgamento em argilitos do Subgrupo Itararé, a norte de Porto Feliz (modif. de Washburne 1930): 1 - Estratificação; 2 - Arenitos; 3 Superfícies dobradas; 4 - Falhas de cavalgamento

\section{Feições reconhecidas no Paraná}

Em corte na estrada a $4 \mathrm{~km}$ de Sengés (ponto 13) há arenitos notavelmente estratificados, separados por plano discreto de deslizamento subaqüoso de material roxo-cinza siltoso, contendo seixos e até calhaus. Muitas falhas cortam o material deslizado, que apresenta camadas lenticulares descontínuas separadas pelo material conglomerático suportado pela matriz. Um sistema de falhas conjugadas forma arranjo em dominó com deslocamento da parte superior para N. Mesmo internamente, as grandes massas de arenito bem preservadas mostram deformações que guardam relação com o deslizamento subaqüoso. No conjunto, parece ter havido muita movimentação das massas de rochas conglomeráticas (diamictitos) com participação passiva das lentes de arenito. 
Em corte a 300 m do trevo de Tomazina na estrada para Siqueira Campos (ponto 14) ocorre arenito fino bege rosado, com estratificação suavemente ondulada, sugestiva de deslizamento subaqüoso. Não aparecem seixos ou calhaus.

O corte do km 141 (ponto 18) da Rod. BR153, sentido Ibaiti para Ventania, expõe dobra elástica em formato de laço, descrita por Vesely et al. (2005, ponto 3) como feição diapírica (Fig. 12). O ápice do lado sul é espessado e isoclinal, enquanto a dobra do lado norte é fechada, com espessura mais uniforme. Predomina siltito bege róseo, com níveis de arenito grosso a médio, também bege, portador de uma espécie de clivagem disjuntiva em planos sub-horizontais. No ponto 19, situado na Rod. Ventania-Curiúva, descrito por Vesely et al. (2005, ponto 2), há siltitos cinza-amarelados repletos de seixos arredondados de diferentes diâmetros. O siltito é arenoso, com aspecto empastilhado, sendo cortado por falhas subverticais. Provavelmente, este evento acontecera junto com os deslizamentos. Algumas superfícies de falha são suavemente arqueadas.

Na Estrada Telêmaco Borba-Tibagi (corte descrito por Vesely et al. 2005, ponto 1), bancos subhorizontais lenticulares de arenitos médios exibem coloração amarelo-avermelhada. Ocorrem zonas irregulares de diamictitos com seixos bem arredondados de quartzo e granito, até calhaus. Não foi possível observar evidências de deformação. Junto à ponte do rio Conceição, $500 \mathrm{~m}$ adiante (ponto
22), ocorre intercalação de arenito médio a grosso na base, com diamictitos e conglomerados para o topo do afloramento. O nível de arenito é ondulado e o contato com o diamictito é brusco. O nível de diamictito possui estratificação plano-paralela e passa abruptamente para o nível de conglomerado, também com estratificação plano-paralela.

\section{Feições reconhecidas em Mafra (SC)}

Assine et al. (1998) atribuem à atividade eocarbonífera da Falha de Lancinha-Cubatão o fato de as rochas sedimentares do Grupo Tubarão repousarem diretamente no embasamento cristalino em Santa Catarina, sendo ausentes os sedimentos da Fm. Ponta Grossa. Esses autores admitem que, no bloco alto dessa falha (sudeste), as camadas devonianas tenham sido completamente removidas por erosão.

Estruturas que parecem ter sido formadas devido à compactação diferencial de siltitos de cor cinza ocorrem em Mafra (ponto 24), em inconfundível corte de paredes verticais na BR-116, km 03, situado próximo ao acesso para a rodovia que leva a Rio Negrinho e Florianópolis. Observaramse marcas de onda nos arenitos e a ocorrência de falhas normais que cortam indistintamente os arenitos e os siltitos, com caimento para W. Nos pacotes superiores, de coloração marrom, predominam siltitos.

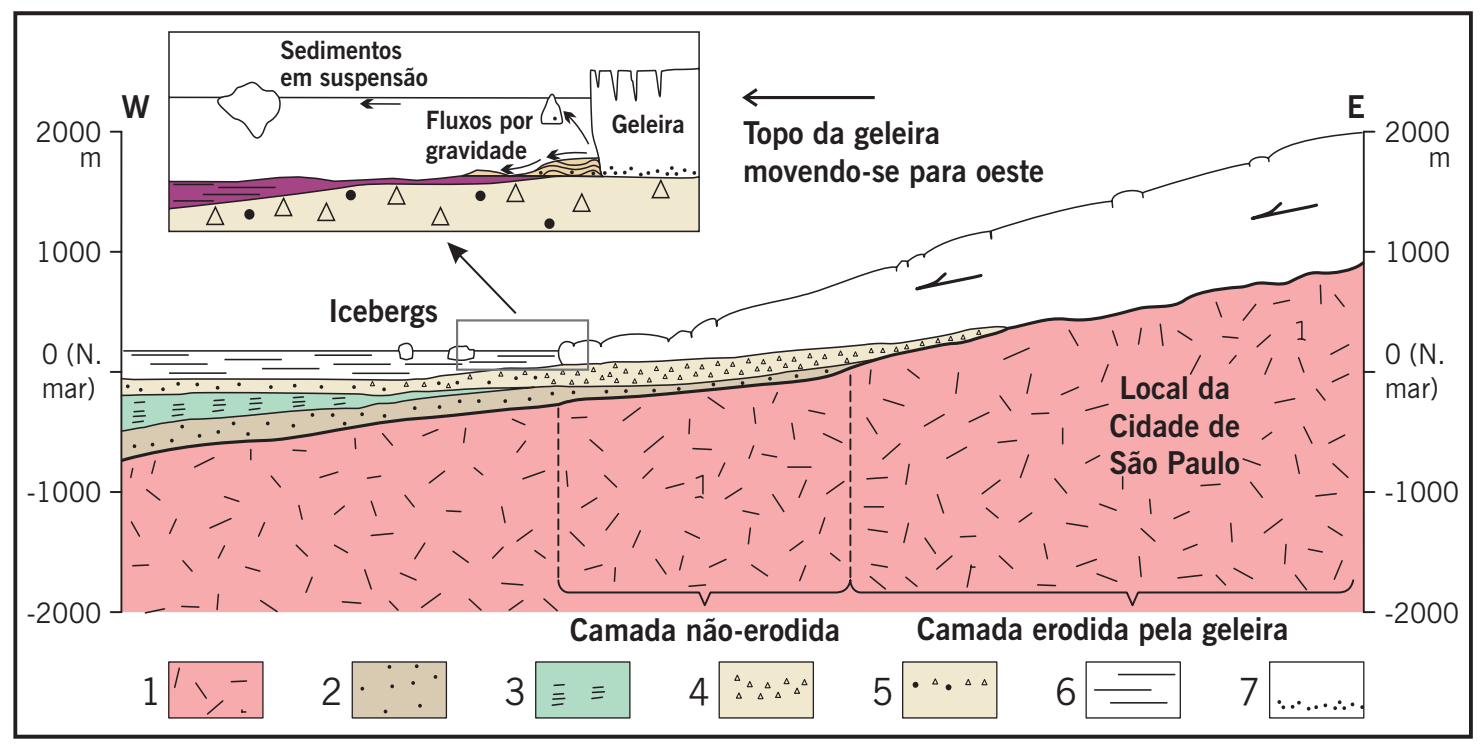

Figura 11 - Distribuição de geleiras carboníferas durante um verão hipotético (perfil baseado em Washburne 1930 e box baseado em Vesely e Assine 2004): 1 - Embasamento; 2 - Arenito Furnas; 3 - Folhelho Ponta Grossa; 4 Arenito glacial; 5 - Till; 6 - Pelitos; 7 - Seixos contidos no gelo 


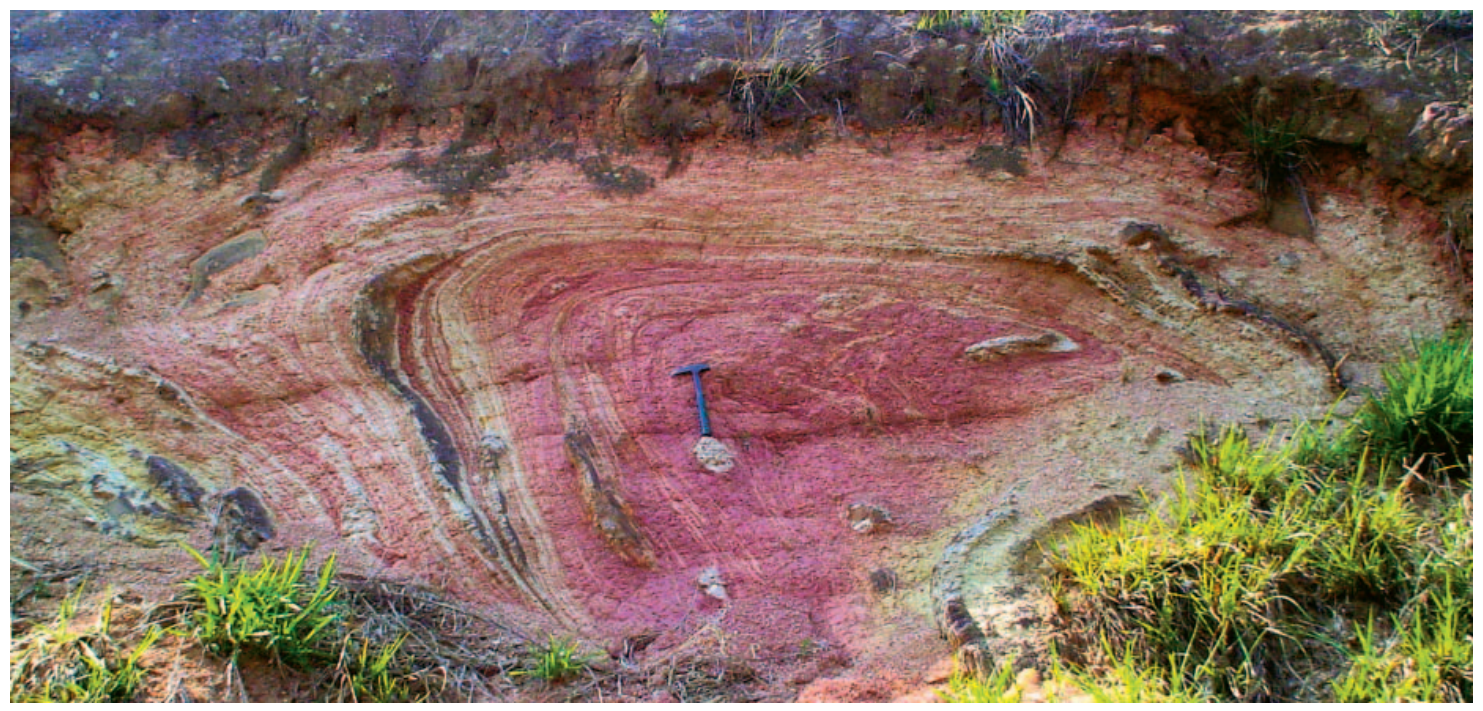

Figura 12 - Visão do corte do km 141 da Rod. BR 153, sentido Ibaiti-Ventania, com dobra elástica em formato de laço, descrita por Vesely et al. (2005) como feição diapírica

Nos trechos da BR-116, entre as saídas que levam a Canoinhas e Itaiópolis, ocorrem arenitos muito finos intercalados com siltitos fraturados, levemente amarelados. Em virtude do adiantado estágio de decomposição das rochas, não se observam outras estruturas além do acamamento. Registrese contudo a detalhada descrição do ponto 25 (Medeiros 1971): "intercalações de arenito muito fino-siltito e argilito em camadas centimétricas e lâminas. Ao longo de certas camadas observam-se deformações de carga bem desenvolvidas em formas de chevrão". Do mesmo modo, no ponto 26, Medeiros (1971) descreve:

“(...) afloramento do intervalo superior da Formação Itararé com intercalações de arenito muito fino e argilito em camadas centimétricas e laminações paralelas. São freqüientes as marcas onduladas simétricas e a laminação ondulada da corrente desenvolvendo localmente estruturas flaser. Alguns niveis mostram dobras convolutas que passam lateralmente a acamamento e laminação paralela. Sobre esta seqüência ocorre arenito muito fino com estratificação cruzada".

Na Pedreira municipal Pedra Branca, em Mafra (ponto 27), cujo acesso se faz pela rodovia de Rio Negrinho, tomando-se o ramo que conduz às margens do rio Negro, ocorrem belas exposições de diamictitos de matriz siltosa, cor cinza médio, repletos de
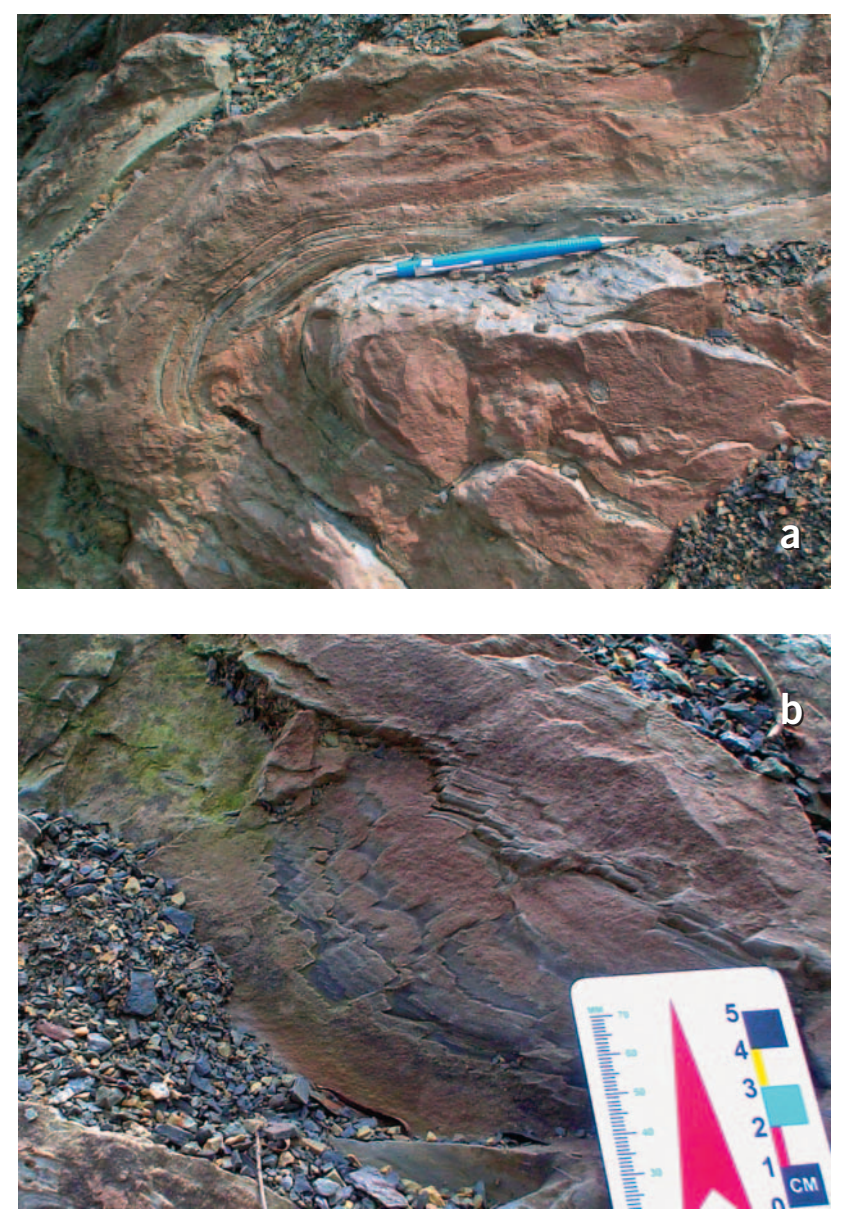

Figura 13 - Exemplos de estruturas atectônicas na pedreira municipal Vila Rutz, em Mafra (SC):

(a) charneira de dobra de plano-axial sub-horizontal, (b) pequenas falhas escalonadas distensivas, encontradas próximas às dobras 
pequenos seixos de tamanhos variados e arredondados. A rocha tem sido britada para pavimentação de estradas de terra, apresentando fraturas conchoidais que refletem sua consistência quando inalterada. Os seixos dispersam-se na matriz sem qualquer orientação ou padrão.

$\mathrm{Na}$ base do pacote de diamictitos cinza-escuro que constitui a variedade litológica dominante da pedreira municipal inativa Mazon, em Mafra (ponto 28, Tab. 3), ocorre ritmito laminado várvico semelhante àqueles observados na cidade de Itu. As camadas, em alguns pontos, exibem atitude levemente basculada.

Em função dos dados coletados, o local mais notável de estruturas atectônicas de Mafra é a pedreira municipal inativa Vila Rutz (ponto 29), onde ocorre um diamictito de matriz siltosa, intercalado com bancos deformados de turbiditos. As camadas em alguns locais são contínuas, mas em outros pontos exibem forte deformação, revelada pelas ondulações abertas a fechadas (Fig. 13a) e pequenas falhas (Fig. 13b).

\section{Origem das estruturas}

Marques Filho et al. (1965) admitem que parte das dobras que descrevem na região de Rio Negro-Mafra possa ser atribuída ao gelo flutuante que teria "arrastado sedimentos inconsolidados do fundo". A maioria das feições observadas, porém, seria de origem heterogênea, "sem relação direta com a ação mecânica das geleiras”. Ponderam que várias delas estariam relacionadas a deslizamentos subaqüáticos (slumps), enquanto outras estariam conectadas a "certos tipos de 'deformação por recalque' (load casting)" (Marques Filho et al. 1965, p. 24).

Segundo Vesely et al. (2005), pelo menos quatro estilos deformacionais podem ser identificados em rochas do Subgrupo Itararé, com base nas assembléias de feições dominantes: (a) falhas normais e basculamento de camadas; (b) superfícies de deslizamento intraestratais e dobras; (c) sobrecarga, diapirismo e dobras e, finalmente, (d) dobras e falhas de empurrão. Esses autores analisaram a geometria, o regime das estruturas deformadas e a natureza dos depósitos associados, tendo classificado as quatro assembléias em regimes distensivos, que incluem as duas primeiras classes, e compressivos, para as duas restantes.

Estilos deformacionais distensivos são caracterizados por falhas lístricas com rejeito máximo de poucos metros e superfícies de deslizamento in- terestratais. As superfícies de deslizamento desenvolveram-se ao longo de descontinuidades préexistentes capeadas por argila, o que facilitou o deslocamento entre as camadas arenosas e também contribuiu para preservação de estrias de atrito em algumas superfícies. $\mathrm{O}$ afloramento mais significativo com relação a este tipo de estilo deformacional é o ponto 13 (Tab. 3). Não houve dificuldade de localizar os pontos indicados por Medeiros (1971) porém, depois de três décadas, os afloramentos se deterioraram, não permitindo levantar dados novos. Nesses locais, o trabalho de campo permitiu apenas identificar o tipo de material presente e suas características, não sendo possível acrescentar dados de caracterização das estruturas.

Os pontos 5, 18 e 19 representam estruturas deformacionais em regime compressivo, sendo as feições mais comuns representadas por dobras com eixos horizontais, desde abertas a isoclinais e recumbentes, com dimensões de até alguns metros. As dobras abertas envolvem camadas arenosas e associam-se a movimentos de massa. Trata-se de dobras isoclinais a fechadas, chegando mesmo a lembrar uma dobra elástica ${ }^{1}$, como observada no ponto 18 (Fig. 10).

Almeida (1953), em seu trabalho clássico Deformações causadas pelos gelos na Série Tubarão em São Paulo, no qual acompanha idéias de Washburne (1930), formula hipótese para a origem das dobras plásticas no Subgrupo Itararé:

“(...) desde seus primeiros cortes já se fazem notar camadas alternadas de arenitos, folhelhos, siltitos e varvitos pronunciadamente perturbadas. (...) Constituem um sistema de deformações plásticas, com predomínio de sucessão de sinclinais e anticlinais assimétricos, revirados ou localmente recumbentes, numa associação desarmônica. (...) A natureza das deformações, sua intercalação em camadas não dobradas e a presença da cobertura de tilito, provam que elas foram causadas pelas pressões transmitidas quando do avanço de grande massa de gelo sobre depósitos lacustres." (Almeida 1953).

Soares et al. (1977) apresentam esboço paleogeográfico para a região de São Paulo (Fig. 14). Além de situar a área no Estado, incluímos dados de ocorrências como a de Jundiaí, onde Neves (1999) descreve pequenas dobras convolutas.

1 Dobra elástica é um tipo de dobra contorcida cujo ângulo de fechamento é superior a $180^{\circ}$. 


\section{Discussão}

\section{Interpretação do afloramento da rodovia D. Pedro I}

Não há tilitos no corte preservado da Rod. D. Pedro I e apenas um pacote de camadas do Subgrupo Itararé apresenta dobramento; acima e abaixo desta, as camadas estão indeformadas e o pacote apresenta inclinação suave para NNW. Carneiro e Costa (2006) atribuem a deslizamento subaqüoso a origem das estruturas, que teriam sido formadas sob regime distensivo envolvendo superfícies de deslizamento intraestratais e conseqüente formação do dobramento, de acordo com a classificação de Vesely et al. (2005). Nessa época, o local localizava-se na borda da Bacia, fator necessário, embora não suficiente, para que o avanço das massas de gelo, atuante sobre pilha relativamente espesssa de sedimentos inconsolidados, superasse a resistência de atrito em determinadas camadas e provocasse deslizamentos.
Dobras em pacotes espessos de até $1 \mathrm{~m}$ já depositados e "que sofrem escorregamento, sem haver regeneração de sedimentos" (Soares et al. 1977) constituem deformações posteriores, porém contemporâneas à sedimentação, que indicam "deposição subaquática em uma superfície de deposição com forte declive". Para Gama Jr. et al. (1992a), a hipótese do deslizamento subaqüoso é mais plausível onde não se observam camadas de diamictito e as formas possuem tamanho relativamente pequeno. No Subgrupo Itararé os deslizamentos subaqüosos seriam fácies de ressedimentação derivadas de processos gravitacionais sob condições abertas e não-confinadas:

“(...) um dos aspectos notáveis das fácies do trato nãoconfinado é a abundância de convoluções e deformações (...) estas deformações são atribuídas a deslizamentos em condições não-confinadas de depósitos ainda não completamente consolidados. Nos depósitos com

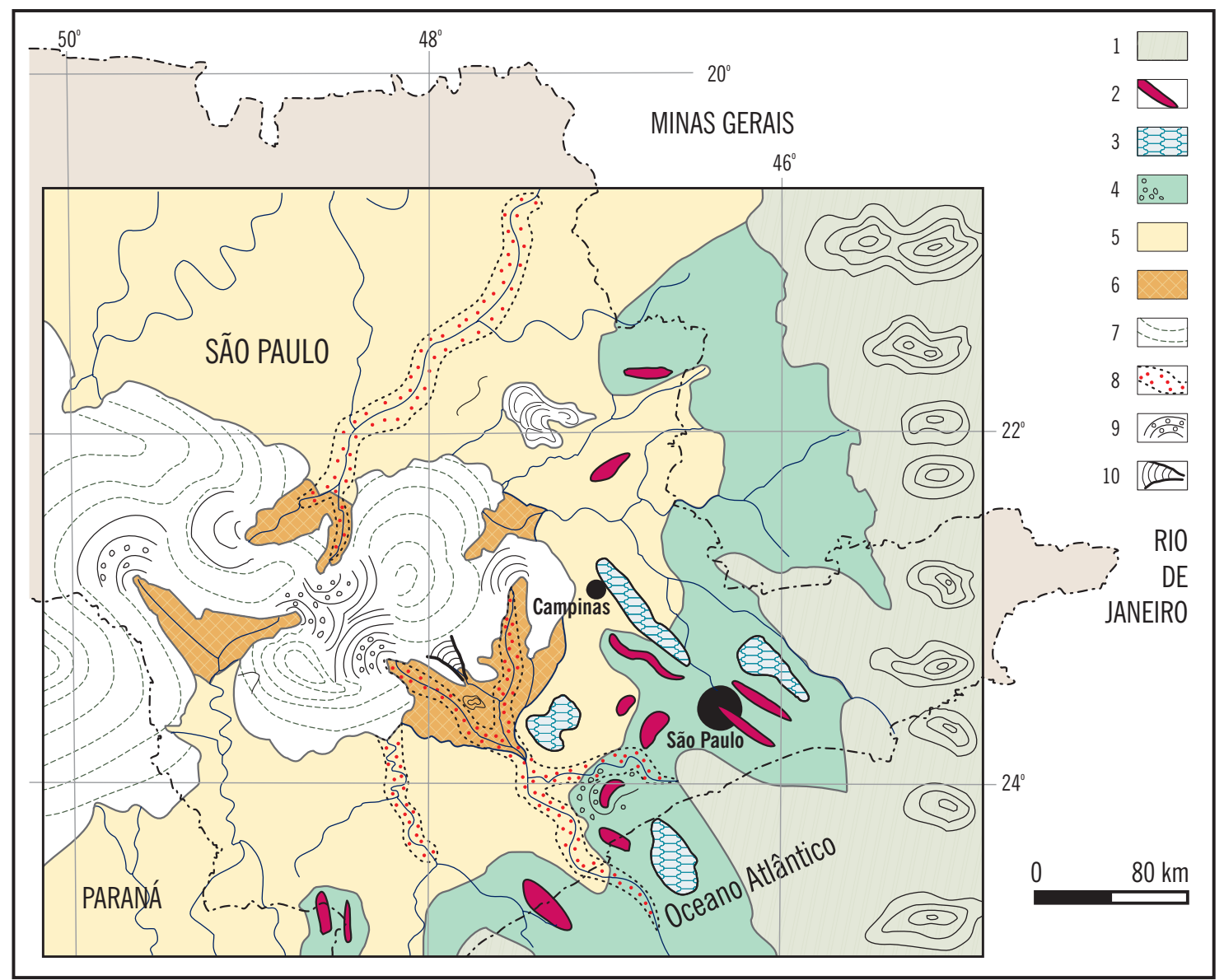

Figura 14 - Esboço paleogeográfico na região centro-leste de São Paulo (modificado de Soares et al. 1977): 1. geleiras; 2. drumlins, eskers; 3. lagos: periglaciais, de planícies aluviais e de planícies deltaicas; 4. outwash, 5. planície aluvial; 6. planície deltaica; 7. plataforma deltaica; 8. canais fluviais com areia e cascalho; 9.escorregamentos em frentes deltaicas; 10. fluxos de areia 


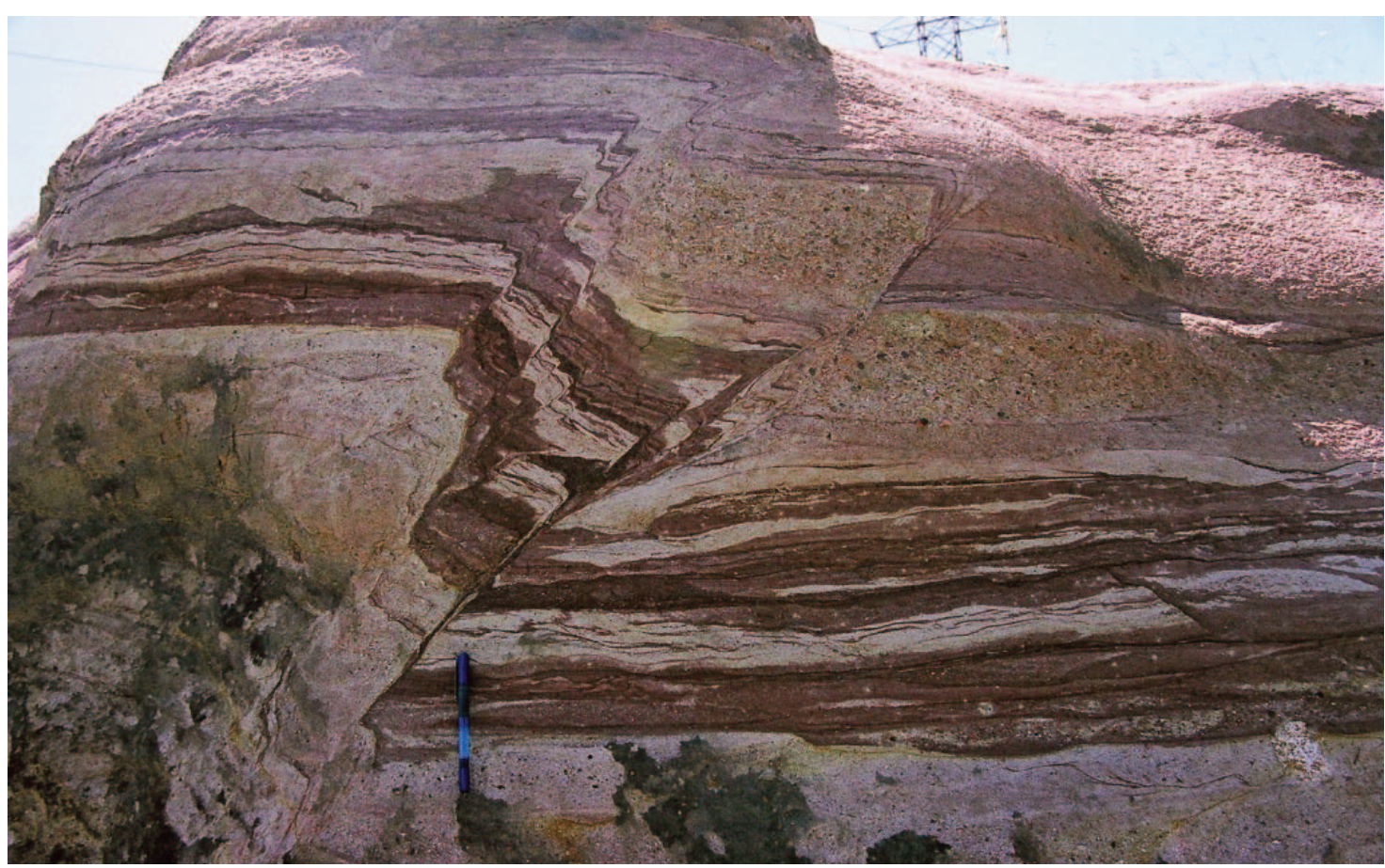

Figura 15 - Falhas inversas em arenitos (tons claros na foto), lamitos (tons escuros) e conglomerados (aspecto pontilhado), bairro DICs, leste de Campinas

deslizamentos foi possivel reconhecer as feições sindeposicionais. Estes deslizamentos representam, em última análise, uma ressedimentação local de fácies de ressedimentação, posto que processos gravitacionais são reconhecidos em ambas as fases." (Gama Jr. et al. 1992a).

$\mathrm{O}$ avanço de massas de gelo deve ter originado feições que afetam grandes volumes de rocha, como os diamictitos siltosos e bancos deformados de turbiditos da pedreira Vila Rutz, em Mafra (ponto 28) e dos cortes em Pilar do Sul (Fig. 9), descritos por Stein (1984). Em Campinas, as grandes ondulações no trevo da Rod. D. Pedro I, cujos comprimentos de onda excedem $20 \mathrm{~m}$, podem ser explicadas por movimentação do gelo. A área é adjacente à zona de outwash de grandes massas de gelo, conforme esboço paleogeográfico da região (Fig. 14). Embora as exposições tenham sido mais tarde destruídas pela continuidade da escavação, em outros pontos ainda é possível visualizar feições associáveis a grandes deslocamentos de rocha, como as falhas inversas (Fig. 15) identificadas em pacote de arenitos, siltitos, argilitos e conglomerados no bairro dos DICs, leste de Campinas. Ali, além do sistema de falhas, possivelmente ligadas a retrocavalgamento, há evidências de retrabalhamento do material sedimentar durante a deposição.

\section{Conclusões}

A Bacia do Paraná possui numerosas ocorrências de estruturas atectônicas, sobretudo na borda oriental, onde afloram rochas do Subgrupo Itararé. A compreensão da origem dessas feições requer análises detalhadas e correlação entre feições similares observadas em diferentes pontos. Feições particulares como dobras convolutas e dobras abertas encontradas em cortes do trevo de acesso da Rod. D. Pedro I à rodovia Campinas / Moji-Mirim / MojiGuaçu, em Campinas (SP), foram descritas nessa nota, tendo em vista preservar os registros por meio de descrições e fotografias. O processo de revegetação artificial dos taludes e as condições efetivas de intemperismo prejudicam hoje a visualização das estruturas. Por outro lado, alguns locais não podem mais ser visitados, e registros importantes foram apagados pelas escavações de 2000-2002 (Fig. 3).

Dentre as hipóteses de formação das estruturas, há duas principais, na literatura regional: deformações causadas por movimentação do gelo ou por deslizamento subaqüoso. Propomos que ambas sejam aplicáveis a dois pontos distintos do local descrito nesta nota. Feições relacionadas a grandes volumes de rocha deformadas do Subgrupo Itararé devem ter sido formadas devido a avanço das massas de gelo, mecanismo que explica as estruturas 
compressivas encontradas em cortes de arenitos, diamictitos e siltitos no trevo estudado (Fig. 3) e outros locais citados neste artigo. As feições referidas em detalhe nas representações de dobras convolutas (Figs. 4 e 5) devem-se à incidência local de deslizamentos subaqüosos causados por processos gravitacionais sob condições abertas e não-confinadas. Esse mecanismo explica a bela sucessão de dobras fechadas a isoclinais (Fig. 1), portadoras de planos axiais empinados e notavelmente encurvados.

\section{Agradecimentos}

Os autores agradecem o apoio do FAEP/Unicamp, cujos recursos possibilitaram a realização de viagem de campo, e do Programa PIBIC-CNPq, mantido pelo Conselho Nacional de Desenvolvimento Científico e Tecnológico - CNPq, que concedeu bolsa de iniciação científica, essencial para o amadurecimento acadêmico do aluno de graduação em Geologia Felipe Garcia Domingues da Costa. Agradecem ao prof. dr. Mario L. Assine, do IGCE-UNESP, que fornecera a exata localização de sete afloramentos que embasaram seu trabalho publicado no Simpósio Nacional de Estudos Tectônicos (2005), relatando estruturas semelhantes ao longo da Bacia do Paraná, e a gentil colaboração de Luiz Claudio Rodrigues, Secretário de Obras e Luiz Carlos Weinschütz, geólogo da Prefeitura de Mafra (SC), que acompanharam os autores durante visita a três pedreiras ativas e inativas da prefeitura que apresentam afloramentos com estruturas semelhantes. Agradecem a dois revisores da revista Terre Didatica, cujas sugestões ajudaram a melhorar o texto.

\section{Referências bibliográficas}

Almeida F.F.M.de. 1945. Depósitos de origem glacial no território de Ponta Porã. An. Acad. brasil. Ciênc., 17(1):1-12.

Almeida F.F.M.de 1948. A "roche moutonnée" de Salto, Estado de São Paulo. São Paulo, Esc. Politécnica/USP, Geologia e Metalurgia, (5):112-118.

Almeida F.F.M.de 1953. Deformações causadas pelos gelos na Série Tubarão em S. Paulo. Rio de Janeiro, DNPM-DGM. 5 p. (Notas Prel. e Estudos 64).

Almeida F.F.M.de, Barbosa O. 1953. Geologia das quadrículas de Piracicaba e Rio Claro, Estado de S. Paulo. Rio de Janeiro, DNPM-DGM. 96 p. (Bol. 143).

Almeida F.F.M.de, Carneiro C.D.R. 1995. Geleiras no Brasil e os parques naturais de Salto e Itu. Ciência Hoje, 19(112):24-31.
Almeida F.F.M.de, Carneiro C.D.R. 2004. Inundações marinhas fanerozóicas no Brasil e recursos minerais associados. In: V. Mantesso Neto, A. Bartorelli, C.D.R. Carneiro, B.B.de Brito-Neves (orgs.). 2004. Geologia do Continente Sul-Americano: Evolução da obra de Fernando Flávio Marques de Almeida. São Paulo: Ed. Beca. p. 43-60. (Cap. 3).

Assine M.L., Fúlfaro V.J., Perinotto J.A.J., Petri S. 1998. Progradação deltaica Tibagi no devoniano médio da Bacia do Paraná. Rev. Bras. Geoc., 28(2):125-134.

Barbosa O., Almeida F.F.M.de. 1949. Nota sobre a estratigrafia da Série Tubarão em São Paulo. An. Acad. brasil. Ciênc., 21(1):65-68.

Caetano-Chang M.R., Oliveira J.P.de, Brighetti J.M.P. 1990. Pavimento estriado em rochas do Subgrupo Itararé ao longo do rio piritubinha, sul do Estado de São Paulo. Rev. Bras. Geoc., 20(14):333-335.

Canuto J.R., Santos P.R., Rocha-Campos A.C. 2001. Estratigrafia de seqüências do Subgrupo Itararé (Neopaleozóico) no leste da Bacia do Paraná, nas regiões sul do Paraná e norte de Santa Catarina, Brasil. Rev. Bras. Geoc., 31(1):107-116.

Carneiro C.D.R. Costa F.G.D.da. 2006. Novas estruturas atectônicas do Subgrupo Itararé em Campinas (SP) In: CONGRESSO Brasileiro de Geologia, 43, Aracaju, 2006. Anais... Aracaju, SBG. p. 36. (S07:AO-107)

Costa F.G.D.da, Carneiro C.D.R. 2006. Integração de dados de estruturas atectônicas do Subgrupo Itararé nas adjacências de Campinas (SP). Campinas: Instituto de Geociências, Unicamp. 13p. (Bolsa Inic. Cient., Rel. Final, PIBIC-CNPq).

Derby O.A. 1878. Geologia da região diamantifea da Província do Paraná no Brasil. Arch. Mus. Nac., Rio de Janeiro, 3:89-96.

Fulfaro V.J., Suguio K., Landim P.M.B., Bósio N.J. 1971. Bacia do Paraná. In: CONGRESSO Brasileiro de Geologia, 25, São Paulo, 1971. Roteiro das Excursões... São Paulo, Sociedade Brasileira de Geologia. p. 29-48. (Exc. n³).

Gama Jr., E.G., Perinotto J.A.J., Ribeiro H.J.P.S., Padula E.K. 1992a. Contribuição ao estudo da ressedimentação no Subgrupo Itararé: tratos de fácies e hidrodinâmica deposicional. Rev. Bras. Geoc., 22(2):228-236.

Gama Jr., E.G., Perinotto J.A.J., Ribeiro H.J.P.S., Padula E.K. 1992b. Contribuição ao estudo da ressedimentação no Subgrupo Itararé: um guia temático de campo. Rev. Bras. Geoc., 22(2):237-247.

Hobbs B.E., Means W.D., Williams P.F. 1976. An outline of structural geology. New York: John Wiley. $571 \mathrm{p}$. 
Loczy L.de, Ladeira E.A. 1976. Geologia Estrutural e introdução à Geotectônica. São Paulo: Blücher, Rio de Janeiro: CNPq. 528p.

Marques F P.L., Salamuni R., Sobanski A. 1965. Contribuição à Geologia da Área Rio Negro-Mafra (Estados do Paraná e Santa Catarina - um resumo) In: CONGRESSO Brasileiro de Geologia, 19, Curitiba, 1965. Instituto de Geologia da Universidade do Paraná, 25p.

Medeiros, R. A. 1971. Bacia do Paraná. Simpósio Geologia do Petróleo no Brasil. In: CONGRESSO Brasileiro de Geologia, 25, São Paulo, 1971. Roteiro das Excursões... São Paulo, SBG. p. 15-25. (Exc. 2).

Mendes J.C. 1962. Problemas paleogeográficos e estratigráficos do Grupo Tubarão; Carbonífero Superior. Bol. Soc. Bras. Geol., 11(2):71-74.

Mezzalira S. 1969. Geologia de Subsuperfície em Itu, SP - ocorrência de "Rocha Moutonnée" nos testemunhos de sondagem. An. Acad. Brasil. Ciênc. 41(1):83-89.

Mezzalira S., Azevedo A.A.B., Tominaga L.K., Pressinotti M.M.N., Massoli M. orgs. 1981. Léxico estratigráfico do Estado de São Paulo. São Paulo, Instituto Geológico. 161p. (Boletim 5).

Neves M.A. 1999. Evolução cenozóica da região de Jundiaí $(S P)$. Rio Claro, IGCE-UNESP. 141p. (Dissert. Mestr. URL: <http://www.biblioteca.unesp.br/ bibliotecadigital/document/?did $=2605>$. Acesso 08.03.2007).

Oliveira E.P.de. 1929. Ocorrências de folhelhos várvicos no sul do Brasil. Rio de Janeiro, Annaes da Academia Brasileira de Sciencias, 1(3):142-144.

Pacheco J. 1927. Relatório elucidativo do esboço geológico da região comprehendida entre o meridiano $4 .^{\circ}$, rio Itararé e os paralellos $23^{\circ} 34^{\prime}$ e $24^{\circ} 38^{\prime}$. In: Comissão Geográfica e Geológica do Estado de São Paulo, Exploração da região comprehendida pelas folhas topográficas Sorocaba... São Paulo, p. 9-12.

Popp J.H. 1987. Introdução ao estudo de estratigrafia e da interpretação de ambientes de sedimentação. Curitiba: Scientia et Labor. 323p.

Ramsay J.G. 1967. Folding and fracturing of rocks. New York, McGraw-Hill, 567p.

Ramsay J.C., Huber M.I. 1987. The techniques of modern structural geology. V. 2: Folds and Fractures. London: Academic Press, p. 308-700.

Rocha-Campos, A.C. 2002a. Varvito de Itu, SP. Registro clássico de glaciação neopaleozóica. In: C. Schobbenhaus, D.A. Campos, E.T.de Queiroz, M. Winge, M.L.C. Berbert-Born (eds.). Sítios Geológicos e Paleontológicos do Brasil. Brasília: DNPM BRASIL. Departamento Nacional de Produção Mineral (DNPM)/Serviço Geológico do Brasil (CPRM). Comissão Brasileira de Sítios Geológicos e Paleobiológicos (SIGEP). 2002. p. 147-154.

Rocha-Campos, A.C. 2002b. Rocha moutonnée de Salto, SP. Típico registro de abrasão glacial do Neopaleozóico. In: C. Schobbenhaus, D.A. Campos, E.T.de Queiroz, M. Winge, M.L.C. Berbert-Born (eds.). Sítios Geológicos e Paleontológicos do Brasil. Brasília: DNPM BRASIL. Departamento Nacional de Produção Mineral (DNPM)/ Serviço Geológico do Brasil (CPRM). Comissão Brasileira de Sítios Geológicos e Paleobiológicos (SIGEP). 2002. p. 155-160.

Rocha-Campos A.C., Farjallat J.E.S., Yoshida R. 1969. Fácies e Paleogeografia do Subgrupo Itararé na Bacia do Paraná. An. Acad. brasil. Ciênc. 41(2):211-213.

Schneider R.L., Mühlmann H., Tommasi E., Medeiros R.A., Daemon R.F., Nogueira A.A. 1974. Revisão Estratigráfica da Bacia do Paraná. In: SBG, Congr. Bras. Geol., 28, Porto Alegre, 1974. Anais..., Porto Alegre, v. 1, p. 41-65.

Soares P.C., Landim P.M.B., Sinelli O., Wernick E., Wu F.T., Fiori A.P. 1977. Associações Litológicas do Subgrupo Itararé e sua interpretação ambiental. Rev. Bras. Geoc., 7(2):131-149.

Stein D.P. 1984. Esboço da evolução geológica précambriana da folha Pilar do Sul, SP. SF.23-Y-C-IV4. São Paulo: Instituto de Geociências, USP. 159p. (Dissert. Mestrado, inédita).

Trosdtorf Jr. I., Assine M.L., Rocha-Campos A.C., Santos P.R.dos, Tomio A. 2005. Glacially striated, soft sediment surfaces on late Paleozoic tilite at São Luiz do Purunã, PR. An. Acad. brasil. Ciênc., 77(2):367-378.

Twiss R.J., Moores E.M. 1992. Structural Geology. W.H. Freeman \& Co. 532p.

Vesely F.F., Assine M.L. 2004. Seqüências e tratos de sistemas deposicionais do Grupo Itararé, norte do Estado do Paraná. Rev. Bras. Geoc., 34(2):219230.

Vesely F.F., Assine M.L., Rostirolla S.P. 2005. Deformação penecontemporânea no Grupo Itararé, Bacia do Paraná: estilos estruturais, dinâmica sedimentar e implicações paleogeográficas. In: SIMPÓSIO Nacional de Estudos Tectônicos, 10, Curitiba, 2005. Anais... . Curitiba: SBG núcleo PR. (CD-ROM).

Washburne C. W. 1930. Petroleum geology of the state of São Paulo. Com. Geogr. Geol. São Paulo, Brasil. p. 1-282. (Bol. 22).

Submetido em 12 de junho de 2006. Aceito em 8 de novembro de 2006. 